\title{
Walkability Index for Elderly Health: A Proposal
}

\author{
Fernando Alves ${ }^{1, * \mathbb{C}}$, Sara Cruz ${ }^{1, * \mathbb{C}}$, Anabela Ribeiro ${ }^{2}$, Ana Bastos Silva ${ }^{2}$, João Martins ${ }^{1} \mathbb{C}$ \\ and Inês Cunha ${ }^{2} \mathbb{D}$ \\ 1 Department of Civil Engineering, University of Porto, 4200-465 Porto, Portugal; up201306383@fe.up.pt \\ 2 Department of Civil Engineering, University of Coimbra, 3030-790 Coimbra, Portugal; \\ anabela@dec.uc.pt (A.R.); abastos@dec.uc.pt (A.B.S.); uc2012136732@student.uc.pt (I.C.) \\ * Correspondence: alves@fe.up.pt (F.A.); scruz@fe.up.pt (S.C.)
}

Received: 6 August 2020; Accepted: 3 September 2020; Published: 8 September 2020

check for updates

\begin{abstract}
Nowadays, the elderly tend to make more trips: Health benefits resulting from their daily walking routines are an important topic in the context of urban renewal processes. Many health organizations and researchers have demonstrated the influence of the urban environment on walkability levels. This article aims to design a multifactor Walkability Index for Elderly Health (WIEH), capable of associating both the adequacy level of public spaces to elderly walkability, and physical exercise benefits while walking. The methodological approach comprised two main parts: Firstly, a literature review of main reports, legislation, and scientific articles was conducted at the intersection of 'gerontology and physical exercise' with 'urban design and mobility', leading to the selection of four aging-related studies as main contributors to the design of the WIEH; and, secondly, the development of the WIEH was undertaken, based on two premises and designed according to four steps. The first premise defined three systematic areas (urban tissue, urban scene, and safety), variables, and criteria to classify the pedestrian network; and the second premise focused on slopes and stairs in public spaces. The WIEH is divided in four steps: (1) Analyzing public spaces and characterizing their quality for walking, (2) considering the existence of slopes and stairs, (3) calculating different routes for the elderly in their daily routines, or when going to points of interest, and (4) selecting the "heart-friendly route" for elderly people. Adequate walking paths for the elderly can be identified through this innovative approach, with the aim of achieving direct health benefits during their daily routines. Ultimately, the WIEH is capable of supporting decision makers and designers in creating inclusive and age-friendly spaces.
\end{abstract}

Keywords: age-friendly spaces; elderly health; physical activity; active aging; walkability combined index

\section{Introduction}

Nowadays, elderly people tend to travel more, for longer distances, and for various reasons [1-4]. Either as residents or as tourists, elderly people are more active, and health support has become more efficient, as have the different modes of transportation. Gradually, more policies have been taking into account the longevity of society and encouraging the autonomy and independence of older adults [5]. Thus, it is of upmost relevance to study their pedestrian mobility and how to adequately design urban spaces in order to respond to their needs. Pavement physical characteristics, gardens, sidewalks, squares, shops, and public buildings play a key role in pedestrian mobility, access to services, and elderly social involvement [6,7]. Consequently, pedestrian mobility is fundamental for active aging purposes and life quality, by enabling the elderly's social participation and autonomy. The integration of good mobility conditions and accessibility in urban public spaces is crucial in aging, so as to provide easy access to convenient services and facilitate favorable conditions for social interaction [8-10]. A lack of pedestrian mobility policies for the past decades, together with the existence of various barriers in 
public spaces, led to a continuous decrease of elderly people's independence. This situation seriously influences their quality of life, contributing to a diversity of issues: Depression, social isolation, reduced physical endurance, cardiovascular diseases, hypertension, musculoskeletal diseases, mental illness, blindness, and decreased vision; there is also an increased risk of falls. Together, these constitute the major causes of mortality among the elderly population [11-13]. However, personal decisions such as a change of lifestyle may delay the onset of certain diseases. Some empirical evidence shows that it is possible for health growth and positive trends to appear during the aging process [14]. Moreover, built-environment factors have been found to increase elderly walkability levels, as well as the frequency and the length of their physical activities; these factors can be as varied as high housing density, good sidewalk conditions, high intersection density, easy access to public transport, and high land-use mix. Residential neighborhoods with better walkability usually have higher levels of active commuting and physical activities, like walking and running $[15,16]$, which lead to the mitigation of different problems (i.e., overweight, depression, alcohol and drug abuse) and contributes to increased sociability $[17,18]$.

In recent years, due to a growing concern regarding these issues, there has been an increase in the number of studies on the quality of public space, and how it relates to elderly walkability and accessibility to services and activities. Nevertheless, no studies relate age-friendly pedestrian itineraries with the benefits of physical exercise through walking. The literature that presents the different relationships between objectively measured walkability and physical exercise among adults, and how these relate to data on common diseases, comes from the field of geriatrics and medicine [19]. Because the definitions of walkability vary, systematic literature reviews regarding the different aspects of walkability often present very mixed findings [20]. It is still rather difficult to determine a core of consensual common attributes in the study of walking [21]. Moreover, in available literature, no index combines the following three major convergent domains: Quality factors of the public space, elderly walkability characteristics, and the physical effort to attain optimal hearth rate in old age. In fact, most of the existing walkability indexes consider land mix use, accessibility (for example, number of destinations reachable on foot), street connectivity, and pedestrian infrastructure as the sole indicators of higher walkability [22]. Therefore, this study aimed to fill this research gap, by developing a multifactor Walkability Index for Elderly Health (WIEH), capable of measuring the adequacy level of public spaces for elderly walkability and connecting it to physical exercise benefits.

\section{Methodological Approach}

The methodology applied in this research comprised two main phases. In the first, a review (further presented in Sections 3 and 4) of main studies was conducted, including reports, legislation, and scientific papers on two main fields of knowledge: 'Gerontology and physical exercise' and 'urban design and mobility'. The second phase (in Section 5) corresponded to the development of the Walkability Index for Elderly Health (WIEH), here presented conceptually.

The literature review was conducted within three main domains: (1) Elderly walkability characteristics, (2) general qualifying factors of the public space, and (3) existing tools, selected from the literature review, which measure walkability and the quality of public spaces. Beyond the analysis of elderly walkability characteristics and the influence of related urban determinants of walkability, other factors that improve physical activity (and health) were also studied. Therefore, some walkability indicators were selected: Different gait speeds [23-25], the recommended distance between elderly people's dwellings and services [26], heart rate reference values [27,28], average step length $[29,30]$, and average number of steps [30-32]. Nevertheless, some of these indicators-the average step length and the average number of steps-serve only as a basis for index construction, considering that they are also part of the average speed and the expected physical effort for each type of walk/activity. In what concerns public space, a set of quality indicators were selected due to their relevance in the literature review process [33-35], and subsequently aggregated into three sets of components: Urban Tissue, Urban Scene, and Safety (Table 1). 
Table 1. Systematic areas and related urban variables.

\begin{tabular}{ccc}
\hline & Systematic Areas & Set of Urban Variables \\
\hline$(1)$ & Urban Tissue & $\begin{array}{r}\text { Pedestrian surface quality; sidewalk existence and width; } \\
\text { traffic street intersections; existence of stairs; existence of } \\
\text { obstacles; land mix use. }\end{array}$ \\
\hline$(2)$ & Urban Scene & Existence of trees/vegetation; existence of urban furniture. \\
\hline$(3)$ & Safety & Street lighting quality; diversity of information signs. \\
\hline
\end{tabular}

In order to avoid an eventual lack of objectivity when analyzing the physical urban factors that directly influence the walking patterns of elderly people, other variables lacking a consistent physical nature were not considered, such as noise, air pollution, sense of comfort/discomfort, and aesthetic issues. In fact, such variables can act as ephemeral agents in the urban environment, often depending on singular circumstances (celebrations, exhibitions, etc.); therefore, they fail to permanently influence citizens' walking patterns. It should also be mentioned that, in our study, access to public transportation was implicit in elderly people's daily routines, as was the access to public and private services, commerce, leisure areas, etc. Similarly, public transport stops and kiosks were integrated into the 'urban furniture' variable.

In the second phase, the conceptual design of the WIEH was presented based on two initial premises, and further developed in four sequential steps. The first premise included variables regarding the classification of the public space, and thus the quality of pedestrian network; the second considered the influence of slopes and existence of stairs in hindering the walking activity.

The first step- "Classifying the pedestrian network" - concerned the classification of the pedestrian network into four types, represented on a layer through the use of Geographic Information System software. The second step-"Integrating slopes and stairs"-corresponded to the classification of the pedestrian network, including the definition of criteria for slopes and stairs. The third step- "Calculating age-friendly routes"-aimed to position the elderly in relation to their most frequently attended places in their daily routines (e.g., supermarkets, churches, groceries, pharmacies, day-care centers, etc.). The fourth step-“Selecting the heart-friendly route" - which is also the most operational one, concerned the applicability of the Index in urban spaces.

As the WIEH is presented conceptually, the figures that accompany the various steps are only illustrative, simulating a real situation.

The WIEH can help decision makers and designers with finding better aging-friendly solutions for public spaces. It can also inform elderly people and social institutions on the most convenient and healthy itineraries available for the elderly's daily routines, something which it can achieve through several different means (technology devices, apps, cell phones, flyers, urban displays, screens, etc.).

To fully develop this methodology, it is important to first build an appropriate background for the issues under discussion. Therefore, the next section comprises the state of the art regarding the connection between walkability performance and elderly people's health.

\section{Walkability and Elderly Physical Exercise and Health}

Physical activity is important to improve the elderly's quality of life, specifically their health, function, and well-being, and, therefore, to prevent the onset of diseases [36-38]. Evidence shows that physical activity is associated with a number of positive health outcomes, such as increased longevity and decreased risks of cardiovascular disease, improved sleep quality, lower risk of hip fracture and increased bone density, reduced risk of dementia, depression, weight gain, stroke, some types of cancer (e.g., colon, breast, lung), and diabetes mellitus type 2 [37,39-44]. Due to the relevance of physical exercise on the elderly's well-being, different worldwide organizations and experts claim that an elderly person's walk should consist of approximately 30 min per day, or 150 min per week, of moderate-intensity physical activity; this is the necessary baseline to achieve the purpose of reducing 
chronic disease risks and improving overall health. Moreover, should chronic diseases occur, elderly people are expected to remain physically active to the extent that their clinical condition allows. This form of physical exercise can also alternate with $20 \mathrm{~min}$ per day of continuous, vigorous physical activity [28,31,32,42,43,45-51]. In addition, guidelines recommend $75 \mathrm{~min}$ per week of vigorous aerobic activity like running or playing tennis [42,48]. It is important to highlight that any physical exercise derived from daily chores (e.g., shopping, cooking, housework) is insufficient to increase heart rate [48] and achieve direct and visible health benefits; it can, nevertheless, contribute to the reduction of sedentary time [47].

Some studies have estimated the average elderly walking speed and its reduction with aging, as well as the average speed (and its reduction) by age group. In general, healthy elderly people walk on average $7000-10,000$ steps per day, which is equivalent to $30 \mathrm{~min}$ per day of moderate to vigorous physical activity [31]. The group of older-age adults typically averages 100 steps per minute at a brisk pace (walk faster than normal) and can walk at the speed of $1.34 \mathrm{~m} / \mathrm{s}(4.83 \mathrm{~km} / \mathrm{h})$ to $1.56 \mathrm{~m} / \mathrm{s}(5.63 \mathrm{~km} / \mathrm{h})$ on flat paths [30,32]. The results found in existing literature are systematized in Table 2.

Table 2. Walking average speed by age group (adapted from [23-25,52].

\begin{tabular}{ccccc}
\hline \multirow{2}{*}{ Studies/Authors } & \multicolumn{2}{c}{ Younger-Age Adults } & \multicolumn{2}{c}{ Older-Age Adults } \\
\cline { 2 - 5 } & Age Groups & Estimated Walking Speed & Age Groups & Estimated Walking Speed \\
\hline \multirow{5}{*}[52]{} & $30-39$ & $1.34 \mathrm{~m} / \mathrm{s}(4.82 \mathrm{~km} / \mathrm{h})$ & & \\
& $40-49$ & $1.26 \mathrm{~m} / \mathrm{s}(4.54 \mathrm{~km} / \mathrm{h})$ & Over 60 & $1.21 \mathrm{~m} / \mathrm{s}(4.34 \mathrm{~km} / \mathrm{h})$ \\
\hline$[24]$ & $50-59$ & $1.26 \mathrm{~m} / \mathrm{s}(4.54 \mathrm{~km} / \mathrm{h})$ & & \\
\hline$[25]$ & $25-34$ & $1.23 \mathrm{~m} / \mathrm{s}(4.43 \mathrm{~km} / \mathrm{h})$ & & $0.95 \mathrm{~m} / \mathrm{s}(3.42 \mathrm{~km} / \mathrm{h})$ \\
\hline \multirow{2}{*}[23]{} & - & - & Over 65 & $0.80 \mathrm{~m} / \mathrm{s}(2.88 \mathrm{~km} / \mathrm{h})$ \\
\hline & - & - & Over 65 & $0.60 \mathrm{~m} / \mathrm{s}$ to $1.00 \mathrm{~m} / \mathrm{s}$ \\
& & & & $(2.16 \mathrm{~km} / \mathrm{h}$ to $3.6 \mathrm{~km} / \mathrm{h})$ \\
\hline
\end{tabular}

Table 2 shows a visible consensus between authors in what concerns the estimated walking speed for younger-age adults [24,52]. However, regarding the estimated walking speed of adults over 65 , there is a discrepancy between authors, of $0.35 \mathrm{~m} / \mathrm{s}(1.26 \mathrm{~km} / \mathrm{h})$. This value excludes the study by Schimpl et al., [52], which stands apart due to their older-age threshold of 60 years of age, with an estimated value of $1.21 \mathrm{~m} / \mathrm{s}(4.34 \mathrm{~km} / \mathrm{h})$. Yet, the aforementioned difference between the other three studies blurs when considering that Julius et al.'s (2012) estimated walking speed varied between $0.60 \mathrm{~m} / \mathrm{s}(2.16 \mathrm{~km} / \mathrm{h})$ and $1.00 \mathrm{~m} / \mathrm{s}(3.6 \mathrm{~km} / \mathrm{h})$. In fact, all values from the three studies fit well within this interim. Furthermore, the values presented by Schimpl et al. [52] for people over 60 are very close to those attributed by Silva, Cunha, and Silva [24] to their 25-34 age group. This discrepancy might be due to the interviewee sample obtained by Schimpl et al. [52], which possibly included very active older people.

Literature also shows that it is possible to classify the type of physical activity (moderate, vigorous) according to "heart rate" (HR) (Table 3). Moderate activities require an effort of 50 to $85 \%$ of the "heart rate maximum average" (HRMA), while vigorous activities require an effort corresponding to the maximum heart rate for that age $[27,28]$.

From the analysis of the age limits (left column - 65 years to 90 years), one can see that the expected maximum HR for people aged $65(132 \mathrm{bpm})$ corresponds to $66 \%$ of their HRMA at moderate activity and to $77.5 \%$ of their HRMA at vigorous activity. Both values (66\% and $77.5 \%)$ are well balanced regarding the correlation between the target HR zone and the HRMA (50-85\% of HRMA). The same analysis can be applied to people aged 90, whose expected maximum HR corresponds to $65 \%$ of HRMA at moderate activity and to $77.5 \%$ of HRMA at vigorous activity. 
Table 3. Heart rate references. Adapted from [28].

\begin{tabular}{ccc}
\hline & \multicolumn{2}{c}{ Heart Rate (bpm) } \\
\cline { 2 - 3 } & Moderate Activity & Vigorous Activity \\
\hline Age groups (years) & HR Target & HRMA \\
& $50-85 \%$ of HRMA & (220 bpm-age) \\
\hline 65 & $78-132 \mathrm{bpm}$ & $155 \mathrm{bpm}$ \\
70 & $75-128 \mathrm{bpm}$ & $150 \mathrm{bpm}$ \\
75 & $73-123 \mathrm{bpm}$ & $145 \mathrm{bpm}$ \\
80 & $70-119 \mathrm{bpm}$ & $140 \mathrm{bpm}$ \\
85 & $68-115 \mathrm{bpm}$ & $135 \mathrm{bpm}$ \\
90 & $65-111 \mathrm{bpm}$ & $130 \mathrm{bpm}$ \\
\hline (HR = heart rate; HRMA $=$ heart rate maximum average; bpm = beat per minute).
\end{tabular}

Slope surfaces are one of the greatest challenges in walking studies for all age groups, but especially for the elderly. So far, few studies have investigated how walking on inclined surfaces influences the performance and changes the walking patterns of healthy elderly people [53-59]. Furthermore, these studies were more concerned with spatiotemporal gait parameters and energy expenditure when walking uphill and downhill $[54,58]$ and less with direct benefits to elderly people's health. The influence of slopes and of altimetry differences on pedestrian performance is well described in the biomechanics field, starting as early as the 1960s [53]. Regarding the degree of walking difficulty, some studies refer to "oxygen consumption" as an objective indicator of the effort expended by the pedestrian while moving [60]. Other authors [61] mention "heart rate" as an indicator of walking exercise effort. In our study, this second indicator was adopted, in order to maintain the coherence between cross-sectional studies related to our objective. As for the relationship between physical effort (heart rate) and slopes in public spaces, literature also points out related values $[61,62]$ that allow for some conclusions regarding suitable elderly walking paths. The authors analyzed the relation of the heart rate (beats per minute-bpm) with six selected types of slopes (Table 4).

Table 4. Relation between bpm and slope.

\begin{tabular}{cc}
\hline Slope-\% Inclines & Heart Rate/bpm Average \\
\hline $5 \%$ slope* (uphill) & $120 \mathrm{bpm}$ \\
$(0 \%)$ (ground flat) & $105 \mathrm{bpm}$ \\
$-5 \%$ (downhill) & $97 \mathrm{bpm}$ \\
$-10 \%$ (downhill) & $96 \mathrm{bpm}$ \\
$-15 \%$ (downhill) & $100 \mathrm{bpm}$ \\
$-20 \%$ (downhill) & $105 \mathrm{bpm}$ \\
\hline & * Maximum acceptable walking slope [62].
\end{tabular}

Downhill walking effort is, as expected, significantly less than walking upwards on a steep slope street. In the 1990s, Kawamura et al. (1991) concluded that at 12 degrees (21.2\%), the product of step length and cadence (step/minute) decreased significantly for both upslope and downslope walking. Table 4 shows that between the maximum incline ( $5 \%$ slope uphill, corresponding to 2.86 degrees uphill) and the minimum incline (-20\% downhill) there is a large difference in terms of heart beats per minute (15 bpm). Recent legislation and manuals of good practices present some recommendations regarding public space. Based on Portuguese legislation [63] and on the recommendations of the Portuguese Institute for Mobility and Land Transports [62,64], three types of walking inclines were adopted:

- $\quad<5 \%$-Suitable

- $5 \%<x<8 \%$-Acceptable

- $>8 \%$-Inappropriate 
Up to $5 \%$ of inclination, elderly people are not expected to overly exert themselves. Their physical effort should, in fact, parallel a moderate activity ( $120 \mathrm{bpm}$, according to Table 3$)$. Therefore, the $5 \%$ threshold represents the maximum incline that can be considered suitable not only for all-inclusive elderly walkability, but also for people of all age groups with reduced mobility. In addition, inclines between $5 \%$ and $8 \%$ can still be considered acceptable for elderly individuals. Inclines over $8 \%$ are considered steep slopes that require the highest level of physical effort and, consequently, a significant increase in heart rate and muscle fatigue. Also, on higher inclines, pedestrian security decreases. Evidence shows that, during inclined walking, a significant decrease occurs in mean step length, mean cadence, and mean normalized speed [54,58].

Public ramps and stairs are not an equivalent challenge for the elderly. Nevertheless, depending on their nature and maintenance conditions, they can be a good stimulating exercise even for the older-adult age groups, especially when associated with other motivators (urban landscape, views, historic itineraries, etc.). While the difficulty of inclined surfaces depends on their declivity degree, the same is not true for stairs. At a normal pace, stairs are rather taxing to the elderly; however, at a slow and steady pace, they can transform into a health asset. Opting for stairs or inclined surfaces should be encouraged when the elderly individual is capable of it, in cases where public space offers good physical and visual security conditions.

Concerning the elderly's stride, some authors have long been studying the importance of step length for walking performance $[29,30,58,59]$. Step length differs between women and men and naturally decreases with age and the type of walking pace. Öberg et al. [29] calculated step length by gender, age group, and type of walking speed (slow, normal, or fast gait) (Table 5).

Table 5. Step-length average by gender, age group, and gait.Adapted from [29].

\begin{tabular}{ccccccc}
\hline Age Group & Slow Gait & $\begin{array}{c}\text { Female } \\
\text { Normal Gait }\end{array}$ & Fast Gait & Slow Gait & $\begin{array}{c}\text { Male } \\
\text { Normal Gait }\end{array}$ & Fast Gait \\
\hline $60-69$ & $47.5 \mathrm{~cm}$ & $55.3 \mathrm{~cm}$ & $62.5 \mathrm{~cm}$ & $56 \mathrm{~cm}$ & $65 \mathrm{~cm}$ & $73.6 \mathrm{~cm}$ \\
$70-79$ & $47.1 \mathrm{~cm}$ & $54.2 \mathrm{~cm}$ & $60.4 \mathrm{~cm}$ & $52.7 \mathrm{~cm}$ & $61.5 \mathrm{~cm}$ & $71.5 \mathrm{~cm}$ \\
\hline
\end{tabular}

According to Hollman et al. [30], on a walkable flat surface, $57 \mathrm{~cm}$ is the average women's step length and $66 \mathrm{~cm}$ is the average men's step length [30]; these values do not deviate from Öberg et al.'s [29] report on normal gait. Given the purpose of our study-mapping friendly walking routes for elderly people that can be linked to their physical exercise-we only considered an average step length comprising both gender's averages, a more practical standard that is also of easier use for mapping interpretation. Therefore, the adopted average steps lengths are:

(1) Age group 60-69 = 51.8 cm-Slow gait; $60.2 \mathrm{~cm}-$ Normal gait; $68 \mathrm{~cm}$-Fast gait.

(2) Age group 70-79 $=50.1 \mathrm{~cm}$-Slow gait; $57.9 \mathrm{~cm}-$ Normal gait; $66 \mathrm{~cm}$-Fast gait.

Another important factor that influences elderly daily walkability is the location of basic services (e.g., post offices, grocery stores, etc.) [65,66]. These services should be located within $400 \mathrm{~m}$ of elderly people's residences, which corresponds to a 5-min walking distance. Secondary services should be located within $800 \mathrm{~m}[65,66]$ or twice the walking distance when compared to the first group. A good understanding of travel patterns, needs, and factors that influence elderly mobility is necessary, so as to enable an active aging life and, consequently, to maintain an active economic and social participation.

Burton and Mitchell [26] argue that the maximum comfortable walking distance is $500 \mathrm{~m}$, from the elderly person's house to available primary services, warning that elderly people can take twice the walking time when compared with younger adults. Based on the fact that elderly people also need to reach secondary services during their daily routines, which might be located further than the $800 \mathrm{~m}$ previously mentioned, distances above $800 \mathrm{~m}$ are also considered important in this study for investigating and mapping feasible distance-walking routes which favor $30 \mathrm{~min}$ of physical exercise. 
In this context, four levels of physical exercise were defined: (1) Not Considered Physical Exercise, (2) Very Light Physical Activity, (3) Moderate Physical Activity, and (4) Vigorous Physical Activity. Also, four different types of speed were defined for elderly walking routines: (1) Low walking speed, (2) normal walking speed, (3) fast walking speed, and (4) running speed. These are presented in Figure 1, for a walking distance of $500 \mathrm{~m}$.

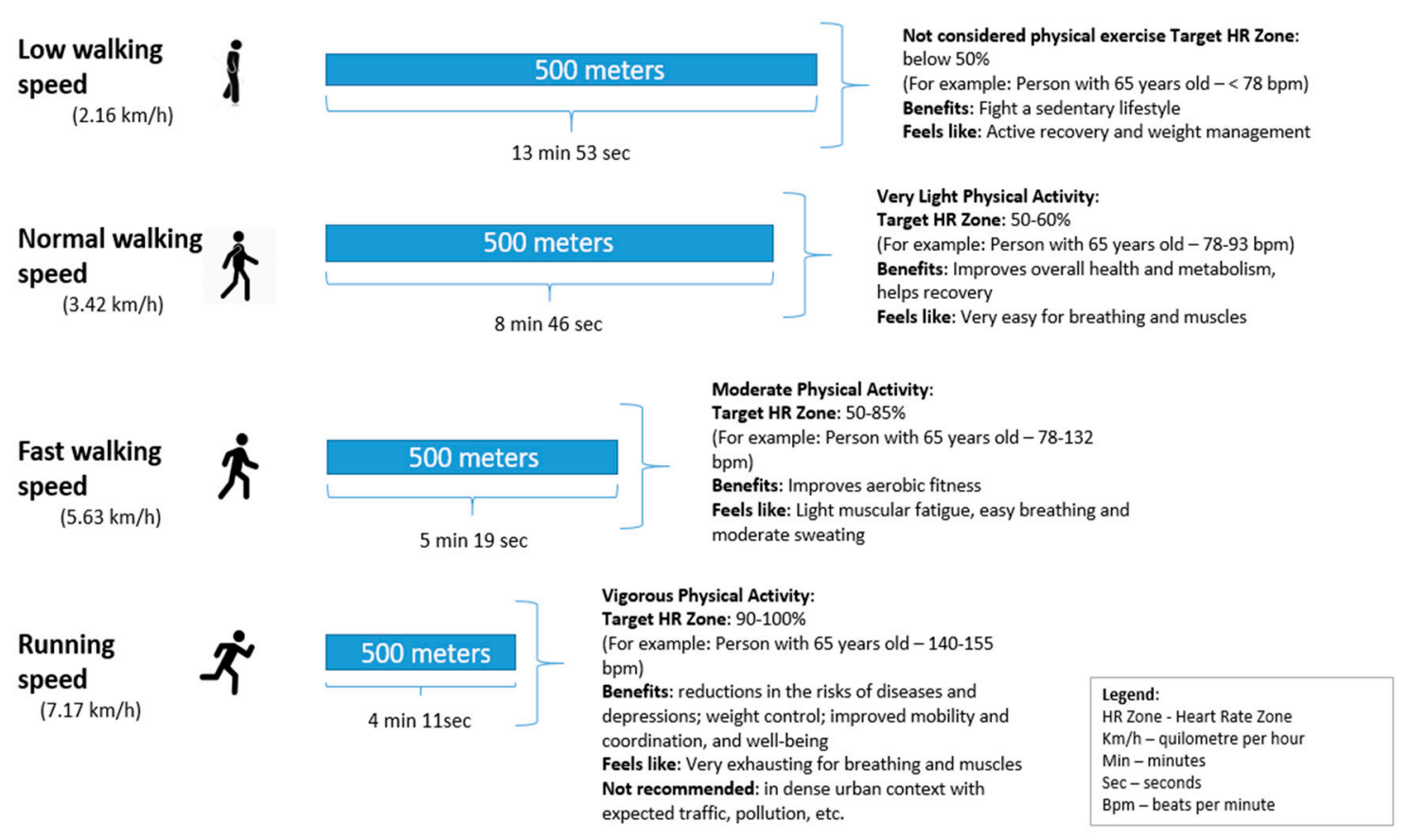

Figure 1. Correlation between different levels of physical exercise, walking speed, and 500-m walking time.

At low walking speed, for elderly people to walk $500 \mathrm{~m}$ at $0.60 \mathrm{~m} / \mathrm{s}(2.16 \mathrm{~km} / \mathrm{h})$, approximately $13 \mathrm{~min}$ and $53 \mathrm{~s}$ will be necessary. In the literature, it is reported that this walking mode is not considered effective physical exercise, since it does induce an increase of the heartbeat. However, as mentioned in the "walkability and elderly health" section, this (more common) activity mode at least counters a sedentary lifestyle, helping in maintaining light activity and weight control. At normal walking speed, an elderly person walks at $0.95 \mathrm{~m} / \mathrm{s}(3.42 \mathrm{~km} / \mathrm{h})$ on average and would take $8 \mathrm{~min}$ and $46 \mathrm{~s}$ to cover the same distance $(500 \mathrm{~m})$. This speed mode requires some physical effort and is expected to increase the heart rate of an elderly person, from $50 \%$ to $60 \%$ of the maximum heart rate, thus being considered light physical exercise. In addition to countering physical inactivity and weight control, this walking mode presents other benefits, allowing elderly people to achieve general improvements in their health status as well as a metabolic balance, and aiding specifically in physical recovery (especially regarding muscle damage). At a fast walking speed (accelerated pace), $5 \mathrm{~min}$ and $19 \mathrm{~s}$ are needed for an elderly person to walk $500 \mathrm{~m}$ at $1.56 \mathrm{~m} / \mathrm{s}(5.63 \mathrm{~km} / \mathrm{h})$, on average. This walking mode is more accelerated than normal and not all elderly people can achieve it; it can even be considered a moderate-intensity form of exercise. This mode forces greater muscle fatigue and better breathing control, with elderly people being expected to reach $50 \%$ to $85 \%$ of their maximum heart rate. One major benefit of this type of exercise is that it can improve individuals' aerobic capacity and, consequently, burn fat tissue. Finally, only elderly people who remain active through a continuous and consistent physical exercise practice are expected to reach the level of effort needed for running speed, which is $1.99 \mathrm{~m} / \mathrm{s}(7.17 \mathrm{~km} / \mathrm{h})$ on average. To travel this distance $(500 \mathrm{~m})$ at this speed, it would take about $4 \mathrm{~min}$ and $11 \mathrm{~s}$, with the elderly person being expected to reach $90 \%$ to $100 \%$ of their maximum heart rate. Relevant benefits of running are related to aerobic resistance growth, the decrease of risk probability of diseases and mental illnesses (i.e., depression), weight control, better motor coordination, and well-being improvement. 
It is urgent to rethink concepts of mobility and "specifically, planned and implemented in a more sustainable, inclusive and integrated manner than has been the case until now" [67] (p. 5). One of the reasons for the lack of inclusiveness (e.g., spaces that can be used by all age groups, genders, (dis)abilities, and ethnicities) is that mobility studies have always paid more attention to utilitarian walking than to recreational walking [68]. The elderly population has specific travel needs, and it is up to urban planners, transportation experts, and public health experts to assist and enable their active life. The importance of "walkable urban environments" must be reflected on these professionals' agendas, as planning for health is one of the growing concerns of the last decades [37,69-71]. Planners must consider opportunities for inclusiveness, such as the concept of promoting a pleasant extension of domestic sociability between neighboring families [70]. Walkable and age-friendly neighborhoods are critical factors of the active aging process, by way of allowing the integration of physical activity into daily routines and fostering social connections $[7,72,73]$. Therefore, green spaces, well-designed and safe streets and sidewalks, accessible walking paths, crosswalks, and cycle paths are fundamental for social interaction support and elderly people's health conditions' improvement.

In the following section, a selective synthesis of the literature review is presented, enhancing the results compiled from studies that refer to different walkability indexes, with a focus on the correspondence between walkability and elderly quality of life.

\section{Walkability Indexes-A Literature Review}

Literature reveals potential conflicts been forms of walkability [20]. According to this author, it is considered that walkability promotes liveliness, sustainable transport options, or exercise. Moreover, it is broadly considered to be centered on good urban design, either because it is multidimensional and measurable or a holistic solution to several human problems. For example, criticism of the walkable neighborhood often comes from those who see it as distracting from more urgent needs, especially affordable housing [74]. Originally based on the categorization of keywords of 45 referenced manuscripts, academics point out the "walking phenomenon" as a key element of Pedestrian Profile, Pedestrian Activity, and Pedestrian Environment-PLACE: Profile, Activity, and Environment [21]. According to Sing [75], evidence shows that face-to-face human interactions in a neighborhood are substantially relevant for supporting livability, economic development, safety and control, civic participation, and identity [76-79]. Other researchers focus their research on the observation of citizens in real-life situations, to determine how the built, urban environment impacts social wellness [80-83]. Consequently, the results of these studies have been leading designers and policy makers to rethink the impact of their plans upon their citizens' real life [75]. Direct observation of real-life situations was not an objective of this study, but its implementation is expected to be part of further works related to our study area.

For the development of this study, investigating whether available literature already possesses some aging-related indexes or tools was a priority, specifically in what concerns the relationship between walking and elderly health. Table 6 presents a selection of the most incisive publications on walkability issues and on older adults' health, aggregated into three major multi-factor domains: "Accessibility", "Urban Design/Walkability", and "Physical Activity and Well-being/Health".

In what concerns the quality of urban public space, four articles refer indexes/tools [15,33-35] that are similar to the Walkability Index for Elderly Health proposed in this study. These four articles highlight key factors, such as walkability and accessibility, that constitute important quality indicators for public spaces. The first one, the Walkability Index (WAI) applied by Reyer et al. [15], was developed by Frank et al. [84] in order to calculate walkability in the context of the International Physical Activity and the Environment Network (IPEN). The WAI is the result of a combination of multiple criteria that measure aspects of walkability, such as the "connectivity index" (also known as intersection densitythe index measures the number of walkable road intersections per square kilometer) and "Shannon's entropy index" (a well-known diversity index from ecological literature, originally proposed by Claude Shannon to quantify uncertainty—entropy or degree of surprise—but that quantifies the level of mixed 
land uses within an area instead). It explains that for a higher mix of land uses, more destinations can be reached by foot, thus making the area more walkable. In its structure, the WAI incorporates two indicators/indexes, the "floor area ratio" and the "household density index". The floor area ratio relates to the intensity of shopping opportunities in a specific area, not only in terms of commercial land use, but also in terms of available retail floor area. If there are high levels of retail floor space in a commercial zone, more pedestrian-friendly shopping opportunities can be expected. The household density index divides the number of households by "living", a land-use category. Higher density values are assumed to be more pedestrian-friendly than lower density values [15]. The WAI final score is a simple aggregation of these indicators, with a double weighting for the connectivity index. However, authors consider that the WAI produces plausible results in terms of the variation of high and low walkability levels throughout the city, and successfully captures variations of the urban form seemingly relevant to walkability. Nevertheless, this methodological approach reveals some weaknesses in its generalization of land-use classes for the land-use mix, as measured by Shannon's entropy index [15] Due to this WAI difficulty, authors used another tool to measure walking friendliness, based on the proximity of important daily life amenities to specific addresses-the Walk Score. This digital platform, composed of two modalities, website and mobile application, can be used for USA, Canada, Australia, and New Zealand addresses $[15,85]$. The Walk Score app measures the walkability on a scale from $0-100$, based on walking routes to destinations [85]. A range of different data products and information are available when accessing and using Walk Score services (e.g., pedestrian-friendliness routes, transit score, bike score, etc.). Data collected by the Walk Score platform can be tracked over time to measure historical trends; for example, it is able to track the percentage of residents in a city area who can walk to the grocery store in $5 \mathrm{~min}$ [85]. Thus, it allows us to evaluate residents' behavior and to think of strategic ways to mitigate eventual public space barriers, which can lead to citizens' reduced mobility.

Another instrument specifically focused on the relation between the urban built environment and adult physical activity was developed in 2014, by Su et al., [33] the China Urban Built Environment Scan Tool (CUBEST). This tool was designed based on a review of existing reliable instruments: Analytic Audit Tool, Active Neighborhood Checklist, Systematic Social Observation (SSO), PIN3 (Pregnancy, Infection and Nutrition) from Neighborhood Audit Tool, Irvine-Minnesota Inventory, Neighborhood Active Living Potential (NALP), Environment in Asian Scan Tool - Hong Kong (EAST_HK), Systematic Pedestrian and Cycling Environment Scan (SPACES), Pedestrian Environment Data Scan (PEDS), Walking/Bicycling Suitability Assessment Form (WABSA), Sidewalk Assessment Tool, and Physical Activity Resource Assessment Instrument (PARA). Furthermore, the CUBEST contemplates six combined factors: (1) Residential density, (2) street connectivity, (3) accessibility (land-use mix), (4) sidewalk quality, (5) bike-lane quality, and (6) aesthetic. Although the CUBEST was designed to analyze a Hangzhou case study, with suitable modifications it can be applied to the study of other worldwide cities. 
Table 6. Review of three major multi-factor domains and related results.

\begin{tabular}{|c|c|c|c|}
\hline Domains & Reference & Subject & Results \\
\hline \multirow{3}{*}{ Accessibility } & [86] & $\begin{array}{l}\text { Accessibility to certain facilities, through the construction of two } \\
\text { indicators: the percentage of citizens living in the surrounding } \\
\text { facilities/services and the percentage of buildings that exist in these } \\
\text { areas. } \\
\text { Case study: Faro (Portugal) }\end{array}$ & $\begin{array}{l}\text { The results indicate a trend towards an effective urbanism of proximity } \\
\text { that can be boosted at the future location of new services. Available } \\
\text { indicators also provide an important contribution to municipal } \\
\text { management, through the definition of structural pedestrian } \\
\text { infrastructures in the city. }\end{array}$ \\
\hline & [87] & $\begin{array}{l}\text { Review of the quantitative and qualitative aspects relevant for } \\
\text { accessibility metrics and empirical studies addressing these aspects } \\
\text { in relation to health. } \\
\text { No case studies }\end{array}$ & $\begin{array}{l}\text { Studies comparing different types of green space indicators suggest } \\
\text { that cumulative opportunity indicators are more consistently and } \\
\text { positively related to health than residential proximity ones. In contrast } \\
\text { to residential proximity indicators, cumulative opportunity indicators } \\
\text { take all the green space within a certain distance into account. }\end{array}$ \\
\hline & $\begin{array}{l}\text { Higgs, C., Badland, H., } \\
\text { Simons, K., [88] }\end{array}$ & $\begin{array}{c}\text { Combination of policy-relevant liveability indicators associated } \\
\text { with health into a spatial Urban Liveability Index (ULI), examining } \\
\text { its association with adult travel behaviours. } \\
\text { Case study: Melbourne (Australia) }\end{array}$ & $\begin{array}{c}\text { Urban Liveability Index (ULI) scores were positively associated with } \\
\text { active transport behaviour: for each unit increase in the ULI score the } \\
\text { estimated adjusted odds ratio for: walking increased by } 12 \% \text {; cycling } \\
\text { increased by } 10 \% \text {; public transport increased by } 15 \% \text {; and private } \\
\text { vehicle transport decreased by } 12 \% \text {. }\end{array}$ \\
\hline \multirow{6}{*}{ Urban Design/Walkability } & [20] & $\begin{array}{l}\text { Review of English-language literature on walkability-from } \\
\text { research, practice, and popular discussions. The review highlights } \\
\text { potential conflicts between forms of walkability. The term is used } \\
\text { to refer to significantly different kinds of phenomena. It clarifies } \\
\text { different types of walkability, focusing on the implications of these } \\
\text { definitions for urban design and planning. }\end{array}$ & $\begin{array}{l}\text { Significant conclusions derived from a better definition of walkability } \\
\text { (i) walkable environments are not all the same; (ii) biases and } \\
\text { assumptions undermine some popular definitions of walkability; (iii) } \\
\text { walkable environments for transportation and recreation purposes } \\
\text { sometimes overlap, but often do not; (iv) while walkability can be } \\
\text { defined in multiple ways, it is broadly considered to be about good } \\
\text { design. }\end{array}$ \\
\hline & {$[81,82]$} & $\begin{array}{l}\text { Observation of people in real-life situations, to determine how the } \\
\text { built environment impacts social wellness. }\end{array}$ & $\begin{array}{l}\text { Important principles to help guide designers in rethinking the impact } \\
\text { of their plans on real life. }\end{array}$ \\
\hline & [21] & $\begin{array}{l}\text { Extensive literature review on the contribution of walking to } \\
\text { sustainable urban development. }\end{array}$ & $\begin{array}{c}\text { Identification of the walking phenomenon as a key-element of } \\
\text { Pedestrian Profile, Pedestrian Activity, and Pedestrian Environment - } \\
\text { PLACE. }\end{array}$ \\
\hline & [89] & $\begin{array}{l}\text { Comprehensive and objective measurement of the subjective } \\
\text { qualities of the urban street environment. }\end{array}$ & $\begin{array}{l}\text { Urban design can explain variation in walking behaviour that urban } \\
\text { form cannot. Observational measures are used to validate digital } \\
\text { measures, which make it possible to study the relationship between } \\
\text { urban design and physical activity. }\end{array}$ \\
\hline & [15] & $\begin{array}{l}\text { Verification of whether the methods used in the US to measure the } \\
\text { suitability of built environments for walking and cycling can be } \\
\text { applied in a European context. } \\
\text { Case study: Stuttgart (Germany) }\end{array}$ & $\begin{array}{l}\text { A noticeable relationship between walkability and active } \\
\text { transportation was found - the more walkable an area was, the more } \\
\text { active residents were. }\end{array}$ \\
\hline & [90] & $\begin{array}{l}\text { Definition of a city's walkability assessment framework capable of } \\
\text { highlighting points of strength and weakness in its urban } \\
\text { environment. } \\
\text { Case study: Milan (Italy) }\end{array}$ & $\begin{array}{l}\text { Design recommendations to make specific evidence-based choices, and } \\
\text { to understand what aspects of the urban environment must be } \\
\text { improved or implemented to promote a walkable city. }\end{array}$ \\
\hline
\end{tabular}


Table 6. Cont.

\begin{tabular}{|c|c|c|c|}
\hline Domains & Reference & Subject & Results \\
\hline & [22] & $\begin{array}{l}\text { Discrepancies within the use of survey data on pedestrian } \\
\text { behaviour; a variety of GIS-derived land use and built } \\
\text { environment measures of neighbourhoods; and socioeconomic } \\
\text { characteristics obtained from the 2011 National Household Survey. } \\
\text { Case study: Montreal (Quebec, Canada). }\end{array}$ & $\begin{array}{c}\text { Some neighbourhoods with higher walking rates are characterized by } \\
\text { a lower presence of parking lots and setbacks, and a greater proportion } \\
\text { of on-street tree canopy. Linear regressions predicting walking rates } \\
\text { confirm these associations, after adjusting for Walk Score and } \\
\text { neighbourhood socioeconomic characteristics. }\end{array}$ \\
\hline & [42] & $\begin{array}{l}\text { Cross-sectional associations between neighbourhood walkability, } \\
\text { crime and physical activity, depending on age and sex of residents. } \\
\text { Case study: Hill District and Homewood (Pittsburgh, USA) }\end{array}$ & $\begin{array}{l}\text { Neighbourhood walkability may play a stronger role in } \\
\text { Moderate-Vigorous Physical Activity than accessible greenspace or } \\
\text { crime in low-income urban communities. Walkability may } \\
\text { differentially impact residents depending on their age and sex, which } \\
\text { suggests tailoring public health policy design and implementation } \\
\text { according to neighbourhood demographics to improve activity for all. }\end{array}$ \\
\hline & [91] & $\begin{array}{c}\text { Review of Australian state-level planning policies and standards } \\
\text { for public open spaces, including policy-specific spatial measures } \\
\text { generated in GIS. } \\
\text { Case study: Australia context }\end{array}$ & $\begin{array}{l}\text { Findings support existing literature, indicating that neighbourhoods } \\
\text { with greater access to public open spaces (within } 400 \text { meters) are } \\
\text { associated with higher odds of physical activity. }\end{array}$ \\
\hline & [92] & $\begin{array}{l}\text { Examination of associations of policy-derived urban design and } \\
\text { empirical measures of POS proximity and density with walking } \\
\text { and depression. } \\
\text { Case study: Australia context }\end{array}$ & $\begin{array}{l}\text { There are complexities in devising and delivering policies that } \\
\text { promote health and wellbeing. However, the findings highlight the } \\
\text { importance of identifying and testing spatial measures for public open } \\
\text { spaces that are associated with health behaviours and outcomes in } \\
\text { different contexts. This type of evidence is required to refine and } \\
\text { strengthen implementation science related to (re)designing public } \\
\text { open spaces, to better support population health outcomes. }\end{array}$ \\
\hline & [38] & $\begin{array}{l}\text { Use of an online participatory mapping method and a novel } \\
\text { modelling of individual activity spaces to study the associations } \\
\text { between both environmental and individual features and older } \\
\text { adults' walking, in environments where older adults move. } \\
\text { Case study: Helsinki Metropolitan Area }\end{array}$ & $\begin{array}{l}\text { Walkway density, residential density, connectivity, and the density of } \\
\text { recreational sport places within respondents' home ranges had an } \\
\text { independent effect on older adults' walking. Residential and public } \\
\text { transit stop density affects the motivation of the elderly to walk. } \\
\text { Well-connected streets/different destinations may encourage the } \\
\text { walking behaviour, even among those who are not very interest in } \\
\text { physical activities. Personal goals related to physical activity also had } \\
\text { a direct positive effect on walking. Additionally, an indirect effect of } \\
\text { gender and of perceived health on walking was found. }\end{array}$ \\
\hline & [44] & $\begin{array}{c}\text { Exploration of three hypotheses: (1) trip purpose as an } \\
\text { independent correlate of utilitarian walking; (2) associations } \\
\text { between environmental attributes surrounding participants' } \\
\text { destinations and walking; (3) association between the distance } \\
\text { travelled and walking. } \\
\text { Case study: Luxembourg }\end{array}$ & $\begin{array}{l}\text { Trip purposes based on free-time activities - including visits to family } \\
\text { and friends, and restaurants and cafés - seem to be less influenced by } \\
\text { the barrier effect of distance on walking. }\end{array}$ \\
\hline
\end{tabular}


Table 6. Cont.

\begin{tabular}{|c|c|c|c|}
\hline Domains & Reference & Subject & Results \\
\hline & [35] & $\begin{array}{c}\text { Development of the Walkability City Tool, in response to a need } \\
\text { stemming from the lack of compiled, precise, objective information } \\
\text { on the walkable network for making strategic urban decisions that } \\
\text { affect pedestrian mobility. } \\
\text { Case study: Financial District of Panama City }\end{array}$ & $\begin{array}{l}\text { Walkability City Tool examines the studied factors via five topics: } \\
\text { Modal Distribution - division of space between the different means of } \\
\text { transportation; Urban Grid - characteristics of the sidewalks; Urban } \\
\text { Scene - information on the environment around us as we walk; Safety - } \\
\text { perception of safety when walking; and Environment - factors that } \\
\text { influence walkers. }\end{array}$ \\
\hline & [16] & $\begin{array}{c}\text { Investigation of the influence of street greenery and walkability on } \\
\text { body mass index. } \\
\text { Case study: Cleveland (Ohio, USA) }\end{array}$ & $\begin{array}{l}\text { The study found that associations between body mass index (BMI), } \\
\text { Walk Score (WS) and Green View Index (GVI) vary among different } \\
\text { age-gender groups. WS has a more significant association with } \\
\text { decreased BMI for males over females. GVI has a more significant } \\
\text { association with decreased BMI for females than males (in } \\
\text { middle-aged and retiree groups). Urban greenery has a stronger } \\
\text { correlation with BMI for females rather than males. }\end{array}$ \\
\hline & [33] & $\begin{array}{l}\text { Development of an urban built environment evaluation tool, with } \\
\text { necessary reliability and validity tests being conducted. } \\
\text { Case study: Hangzhou (China) }\end{array}$ & $\begin{array}{l}\text { CUBEST was developed: a reliable and valid instrument that can be } \\
\text { used to assess the physical activity-related built environment in } \\
\text { Hangzhou, and potentially other cities in China. }\end{array}$ \\
\hline & [34] & $\begin{array}{l}\text { Development of an alternative walking index, the Quality of } \\
\text { Pedestrian Level of Service (Q-PLOS) method. } \\
\text { Case study: Metropolitan Area of Granada (Spain) }\end{array}$ & $\begin{array}{l}\text { The Q-PLOS enabled a more detailed identification of characteristics } \\
\text { related to pedestrian mobility, showing that they can be improved } \\
\text { through mobility strategies of urban design, such as pedestrian } \\
\text { continuity and connectivity of green spaces. }\end{array}$ \\
\hline \multirow{4}{*}{$\begin{array}{l}\text { Physical Activity and } \\
\text { Well-being/Health }\end{array}$} & [93] & $\begin{array}{c}\text { Assessment of both the quantity and quality of street greenery, } \\
\text { associating them with the recreational physical activity occurring } \\
\text { in green outdoor environments, for } 1390 \text { participants in } 24 \text { housing } \\
\text { units. } \\
\text { Case study: Hong Kong (China) }\end{array}$ & $\begin{array}{l}\text { There was a demonstration of the benefit of using Google Street View } \\
\text { for health and physical activity studies. The study provides findings to } \\
\text { recognize the impacts of environmental factors on residents' physical } \\
\text { activity, hence contributing to targeted intervention strategies for } \\
\text { creating activity-friendly urban design. }\end{array}$ \\
\hline & [71] & $\begin{array}{l}\text { Lessons on how the neighbourhood built environment may affect } \\
\text { one aspect - specifically, happiness - of residents' wellbeing. } \\
\text { No case studies }\end{array}$ & $\begin{array}{l}\text { The authors draw lessons from a cross-disciplinary set of studies to } \\
\text { reveal how the neighbourhood built environment may affect one } \\
\text { aspect of residents' wellbeing: happiness. Providing residents with } \\
\text { access to open, natural, and green spaces may directly increase their } \\
\text { happiness. Incorporating design features that allow for social } \\
\text { interaction and safety may also promote residents' happiness. }\end{array}$ \\
\hline & [94] & $\begin{array}{l}\text { Visitors' perceptions and activities in protected areas. } \\
\text { Case study: Barcelona (Spain) }\end{array}$ & $\begin{array}{l}\text { The majority of surveyed park visitors reported that physical health } \\
\text { was an important motivation for visiting parks; a perceived } \\
\text { improvement in their physical health was reported. The most } \\
\text { physically-active recreation activities were more practiced by younger } \\
\text { people. Nearby residents and visitors reported high levels of perceived } \\
\text { physical health, motivation for visiting, and impact of that visit. }\end{array}$ \\
\hline & [95] & $\begin{array}{c}\text { In-depth characterization of a neighbourhood's social and physical } \\
\text { environment, in relation to cardiovascular health. } \\
\text { Case study: Madrid (Spain) }\end{array}$ & $\begin{array}{l}\text { This experience led to the testing and refining of measurement tools, } \\
\text { drawn from epidemiology, geography, sociology, and anthropology, in } \\
\text { order to better understand the urban environment in relation to } \\
\text { cardiovascular health. }\end{array}$ \\
\hline
\end{tabular}


Talavera-Garcia and Soria-Lara [34] developed the Quality of Pedestrian Level of Service (Q. PLOS) method, which aims to evaluate the quality of urban design for pedestrians and its relationship with walking needs. It is used to evaluate three parameters: (1) Pedestrian environments, through the use of urban design indicators related to walking needs, (2) a simple comparison between different case studies, through the definition of quality thresholds, and (3) an output that can be simultaneously presented as an aggregated result and as separate factors. According to walking needs, the authors selected pedestrian factors based on their literature review, namely, accessibility, security, comfort, and attractiveness. Also, five urban design indicators were chosen: Connectivity, pavement width, traffic speed, tree density, and commercial density. The concept of "thresholds" was defined, based on academic references from urban design handbooks and good practice guidelines [34]. The last of the previously mentioned parameters-the output that is simultaneously presented as an aggregated result and as separate factors-addresses the aggregation of quality values obtained in the previous stage for each urban design factor. While the results of each indicator can be shown through separate quality levels, the aggregation of these results into one image pertaining to quality level could provide a global perspective, in order to better compare different mobility environments [34].

Finally, Aranoa et al. [35] used sidewalks as a working base to develop the Walkability City Tool (WCT) and divided the information into five thematic areas: Modal distribution, urban tissue, urban scene, safety, and environment. Cumulatively, the authors also analyzed crosswalks, according to three different perspectives: Delay (the time a person takes to cross a sidewalk), safety, and accessibility. Based on their fieldwork, the authors assigned a classification value to each stretch of sidewalk. Later, by using a geographic information system whose base was developed by the Massachusetts Institute of Technology and applying its calculations to the flow between nodes, the authors undertook a range of different analyses, such as heat maps to assess streets, dysfunctions in the network, and black spots.

Based on these four articles, a list of public space-quality factors to analyze different research areas was built. The next section presents this list and explains the index construction method, step by step.

\section{The Conceptual Design of the WIEH}

The conceptual design of the Index comprised two initial premises. The first included variables regarding the classification of the public space and, consequently, the pedestrian network; the second focused on the influence that slopes and stairs exert on the walking activity. The WIEH builds on these premises, as shown in Figure 2. 


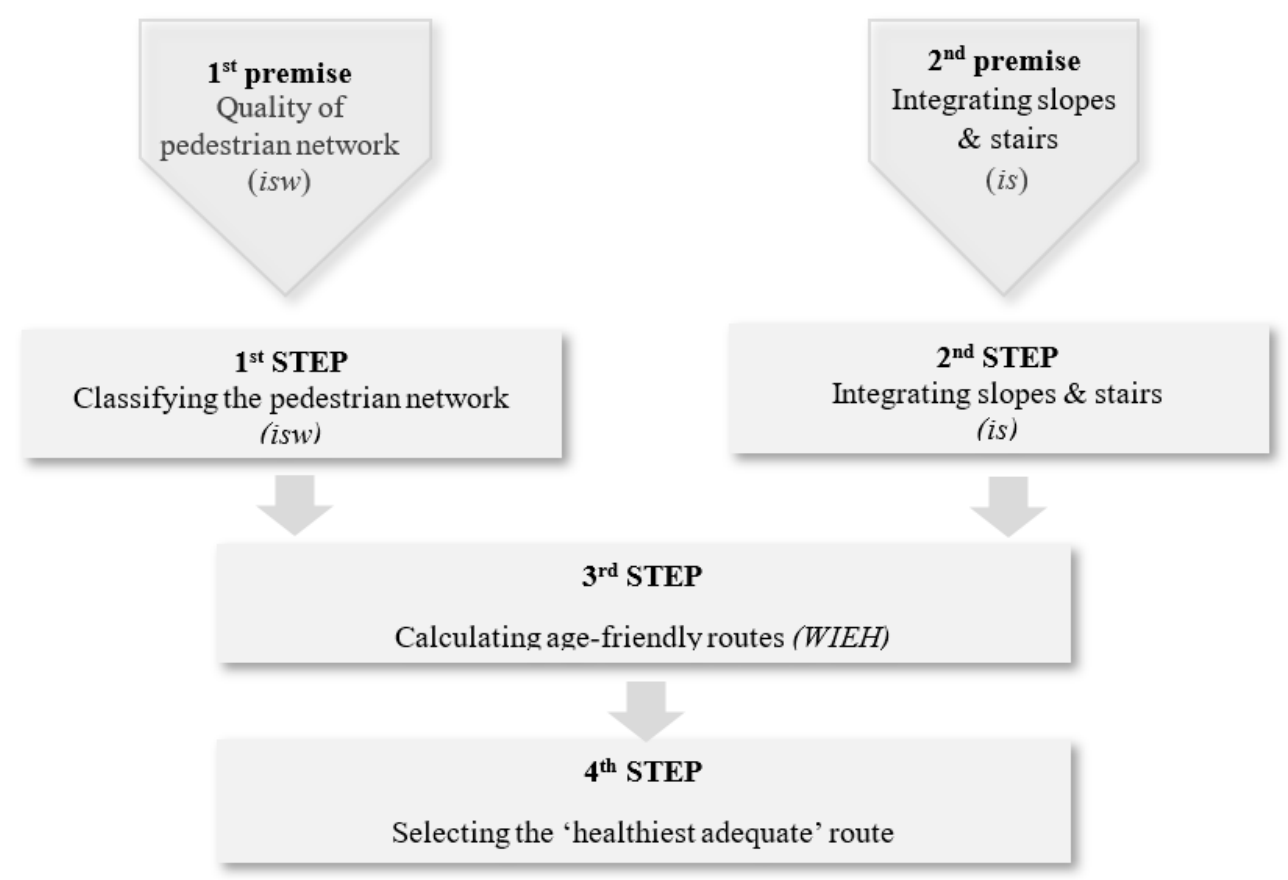

Figure 2. WIEH conceptual design.

\subsection{First Premise: Definition of Variables and Criteria to Classify the Pedestrian Network}

As referred in the previous section, the qualifying factors of public space, obtained from the literature review, were divided into three systematic areas: Urban tissue, urban scene, and safety. Considering that the target was the analysis of space-walkability conditions, the selection of these three systematic areas sustains a complete and effective public-space analysis, through the evaluation of the corresponding variables. For each of the three systematic areas, a set of variables were defined for analysis. Then, a range of values (0-3) was assigned to these variables (Table 7).

Using the table above, the construction of a preliminary index exclusively assigned to public-space conditions was possible: The "isw" - "index of space suitability for walking". The weight distribution took into consideration the levels of importance of the different variables regarding walkable suitability of public space. For instance, the shadow of trees can play an important role when walking during hot days, but their absence does not imply a decrease of walking security. The next formula explains the index calculation:

isw $=$ Urban tissue variables $\times 60 \%+$ Urban scene variables $\times 16 \%+$ Safety variables $\times 24 \%$

isw $=(\mathrm{PQS} \times 0.08+\mathrm{SE} \times 0.06+\mathrm{SW} \times 0.06+\mathrm{TSI} \times 0,12+\mathrm{EoS} \times 0.08+\mathrm{EoO} \times 0.12+\mathrm{LUM} \times 0.08)+$ $(\mathrm{ETV}+\mathrm{EUP}) \times 0.08+(\mathrm{SLQ}+\mathrm{DIS}) \times 0.12)$ 
Table 7. Systematic areas, corresponding variables, and criteria to classify the pedestrian network.

\begin{tabular}{|c|c|c|c|c|c|}
\hline \multirow{2}{*}{$\begin{array}{l}\text { Systematic } \\
\text { Areas }\end{array}$} & \multirow{2}{*}{\multicolumn{2}{|c|}{ Variables }} & \multicolumn{2}{|c|}{ Weight (\%) } & \multirow{2}{*}{$\begin{array}{l}\text { Criteria to Classify the } \\
\text { Pedestrian Network }\end{array}$} \\
\hline & & & Partial Weight & $\begin{array}{c}\text { Total } \\
\text { Weight }\end{array}$ & \\
\hline \multirow{7}{*}{$\begin{array}{l}\text { 1. Urban } \\
\text { Tissue }\end{array}$} & \multicolumn{2}{|c|}{ Pedestrian surface quality (PSQ) } & 8 & \multirow{7}{*}{60} & $\begin{array}{l}1=\text { bad } \\
2=\text { acceptable } \\
3=\text { good }\end{array}$ \\
\hline & \multirow{2}{*}{$\begin{array}{l}\text { Sidewalks existence } \\
\text { and width (SEW) } \\
\text { (Average of SE } \\
\text { and SW) }\end{array}$} & $\begin{array}{l}\text { Sidewalks } \\
\text { existence (SE) }\end{array}$ & \multirow[t]{2}{*}{12} & & $\begin{array}{l}1=\text { none } \\
1.5=\text { one side partial or both } \\
\text { sides partial } \\
2=\text { one side continuous } \\
2.5=\text { one side continuous and } \\
\text { one side partial } \\
3=\text { both sides continuous }\end{array}$ \\
\hline & & $\begin{array}{l}\text { Sidewalks width } \\
\text { (SW) }\end{array}$ & & & $\begin{array}{l}1-\mathrm{SW}<0.90 \mathrm{~m} \\
1.5-0.90 \mathrm{~m} \leq \mathrm{SW}<1.20 \mathrm{~m} \\
2-1.20 \mathrm{~m} \leq \mathrm{SW}<1.50 \mathrm{~m} \\
2.5-1.50 \mathrm{~m} \leq \mathrm{SW}<1.80 \mathrm{~m} \\
3-\mathrm{SW} \geq 1.80 \mathrm{~m}\end{array}$ \\
\hline & \multicolumn{2}{|c|}{ Traffic street intersections (TSI) } & 12 & & $\begin{array}{l}1->3 \\
2-1 \text { or } 2 \\
3-\text { no intersections }\end{array}$ \\
\hline & $\begin{array}{r}\text { Existence of stairs (E } \\
\text { only considered when } \\
3 \text { ste }\end{array}$ & $\begin{array}{l}\text { (note: stairs are } \\
\text { ere are more than }\end{array}$ & 8 & & $\begin{array}{l}1->3 \text { stairs } \\
2-1 \text { or } 2 \text { stairs } \\
\text { 3-no stairs }\end{array}$ \\
\hline & Existence of ob & cles (EoO) & 12 & & $\begin{array}{l}1=\text { systematically affects } \\
\text { walking } \\
2=\text { occasionally affects walking } \\
3=\text { no obstacles }\end{array}$ \\
\hline & Land use $\mathrm{m}$ & (LUM) & 8 & & $\begin{array}{l}1=\text { no land use mix } \\
2=\text { medium land use mix (at } \\
\text { least } 2 \text { different uses) } \\
3=\text { high land use mix ( } 3 \text { or } \\
\text { more different uses) }\end{array}$ \\
\hline \multirow{2}{*}{ 2. Urban Scene } & \multicolumn{2}{|c|}{ Existence of trees/vegetation (ETV) } & 8 & \multirow{2}{*}{16} & $\begin{array}{l}1=\text { no trees/vegetation } \\
2=\text { moderate existence of } \\
\text { trees/vegetation } \\
3=\text { strong existence of } \\
\text { trees/vegetation }\end{array}$ \\
\hline & \multicolumn{2}{|c|}{ Existence of urban furniture (EUF) } & 8 & & $\begin{array}{l}1=\text { no urban furniture } \\
2=\text { moderate existence of } \\
\text { urban furniture } \\
3=\text { strong existence of urban } \\
\text { furniture }\end{array}$ \\
\hline \multirow{2}{*}{ 3. Safety } & \multicolumn{2}{|c|}{ Street lighting quality (SLQ) } & 12 & 24 & $\begin{array}{l}1=\text { bad } \\
2=\text { acceptable } \\
3=\text { good }\end{array}$ \\
\hline & \multicolumn{2}{|c|}{ Diversity of information signs (DIS) } & 12 & & $\begin{array}{l}1=\text { low } \\
2=\text { medium } \\
3=\text { high }\end{array}$ \\
\hline
\end{tabular}

Thus, isw varies between 1 and 3; for each range of index values, an easy-to-interpret color is assigned in Table 8: 
Table 8. Index results of the index of space suitability for walking (isw).

\begin{tabular}{cc}
\hline Index Values (isw) & Result \\
\hline $1-1.5$ & not suitable \\
\hline $1.5-2$ & less suitable \\
\hline $2-2.5$ & suitable \\
\hline $2.5-3$ & most suitable \\
\hline
\end{tabular}

Therefore, the results of the index calculation will vary between " 1 "/"not suitable for walking" (the worst case, generally assigned to neglected public spaces, with low quality and no security) and " 3 "/"most suitable for walking" (the best case, pertaining to public spaces with the best walkability conditions for elderly people, e.g., the best pedestrian networks).

\subsection{Second Premise: Integrating Slopes and Stairs}

Based on Table 4 [61,62], it is possible to establish a connection between inclines and the type of physical effort (data presented for the elderly's heart rate indicator) needed to cover them (premise 2), therefore providing us with detailed information regarding the elderly's path choices. Considering the three types of inclined walking surfaces adopted in our methodology [62-64], it was possible to attribute a heart rate average to different sets of slopes.

(1) "Suitable slopes" ( $\leq 5 \%)$ : HR of $120 \mathrm{bpm}$, representing $55 \%$ of the recommended HRMA; this fits the moderate activity classification, as the value is within $50-85 \%$ of HRMA (Table 3 ).

(2) "Acceptable slopes" ( $>5 \%$ and $\leq 8 \%$ ): It is expected that the HR will always remain under $85 \%$ (the maximum recommended percentage of the HRMA), even with this minor increase, from $5 \%$ to $8 \%$. Thus, these slopes induce a moderate level of activity. Moreover, as mentioned before, evidence shows that the product of step length and cadence starts decreasing significantly between $15.8 \%$ and $21.2 \%$ inclines, in both upwards and downwards walking [59]. As our "suitable slopes" remain under these percentages, all the HR averages are expected to match the recommended values. Subsequent studies did not contradict Kawamura's findings [53,58].

(3) "Steep slopes" (>8\%): These slopes are not recommended for elderly walking.

As mentioned in the "Walkability and elderly health" section, stairs are part of the analysis of spaces, but are not necessarily considered an obstacle to walking. Thus, the three classes of slopes are combined with the (in)existence of stairs in order to calculate "is", index of slopes \& stairs.

Should the "is" equal 4 for a certain route, then said route should be excluded from the walking network.

\subsection{Calculating WIEH—Walkability Index for Elderly Health}

Based on the three premises developed until this point, it is possible to present a final formula to calculate the WIEH:

$$
\mathrm{WIEH}=\frac{\text { isw }}{\text { is }}
$$

with "is" being the slope level (\%) attributed to each space (street, square, other) and varying from " 1 " (flat ground) to " 4 " (inclines over $8 \%$ ). It should be noted that stairs are not considered inclined spaces. In fact, the WIEH starts from the preliminary index (the isw-space suitability index for walking), but at this stage it also integrates the classification of existing slopes, thus allowing us to define a final classification of the suitability of walking paths.

The methodological procedure to apply the WIEH includes four main steps, based on both mentioned premises, as described below. 


\subsection{First Step—Classifying the Pedestrian Network}

The quality factors of the public space mentioned in the first premise were used, in this step, to classify a pedestrian network into four types (see Table 8) and then represented on a layer through the use of GIS software. The values vary between 1 (the worst case, not suitable for elderly walkability) and 3 (the best case, presenting the most suitable conditions for elderly walkability). For the sake of clarity, an abstract urban grid was used (Figures $3-5$ ). The four levels allowed us to understand the adequacy of the public space for elderly walkability.
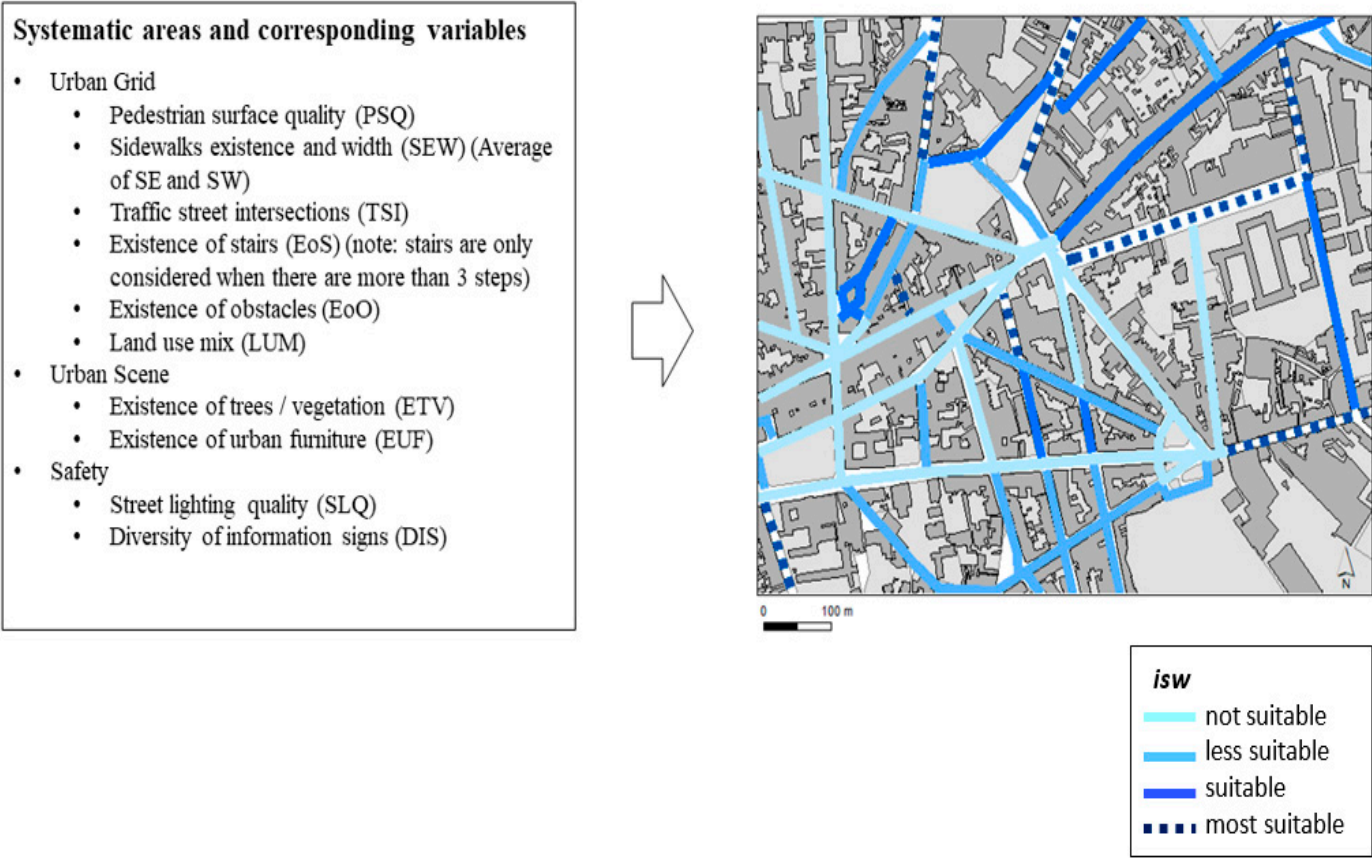

Figure 3. Pedestrian characterization according to the quality factors of public space.

However, keeping in mind that steep slopes and large numbers of steps are not recommended, all sections with is equal to 4 were excluded from the final map.

This step allowed us to exclude segments of the pedestrian network with no quality and adequacy for the elderly. In other words, those whose value equaled 1 . Thus, the main output of this step was to classify the suitability of the pedestrian network for elderly walking. 


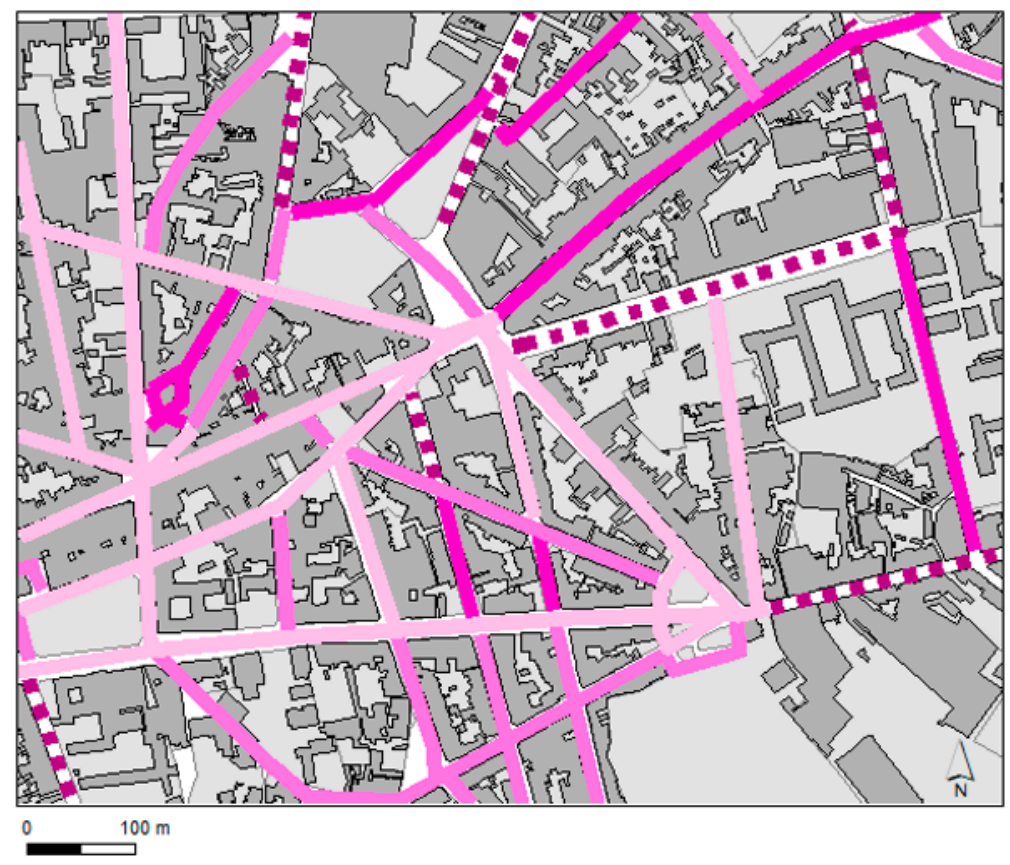

is

Suitable slopes / no stairs

Suitable slopes / few nr. of stairs

Acceptable slopes / significant nr. of stairs

- - - Steep slopes / large nr. of steps

Figure 4. Pedestrian characterization according to slopes and existence of stairs.

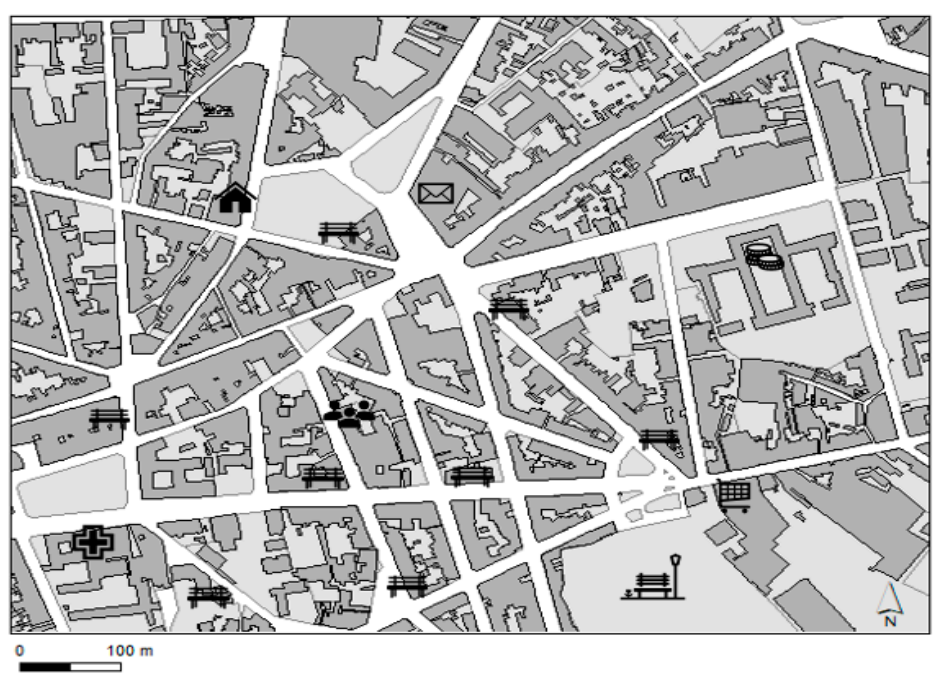

\begin{tabular}{|c|c|}
\hline ^ Home & $\#$ Benches \\
\hline Primary Services: & Secondary Services: \\
\hline 色 Pharmacy & $凶$ Postal Service \\
\hline 贯 Supermarket & 8 Bank \\
\hline$\therefore$ Day Care Centre & 뵤PPark \\
\hline
\end{tabular}

(a)

Figure 5. Cont. 


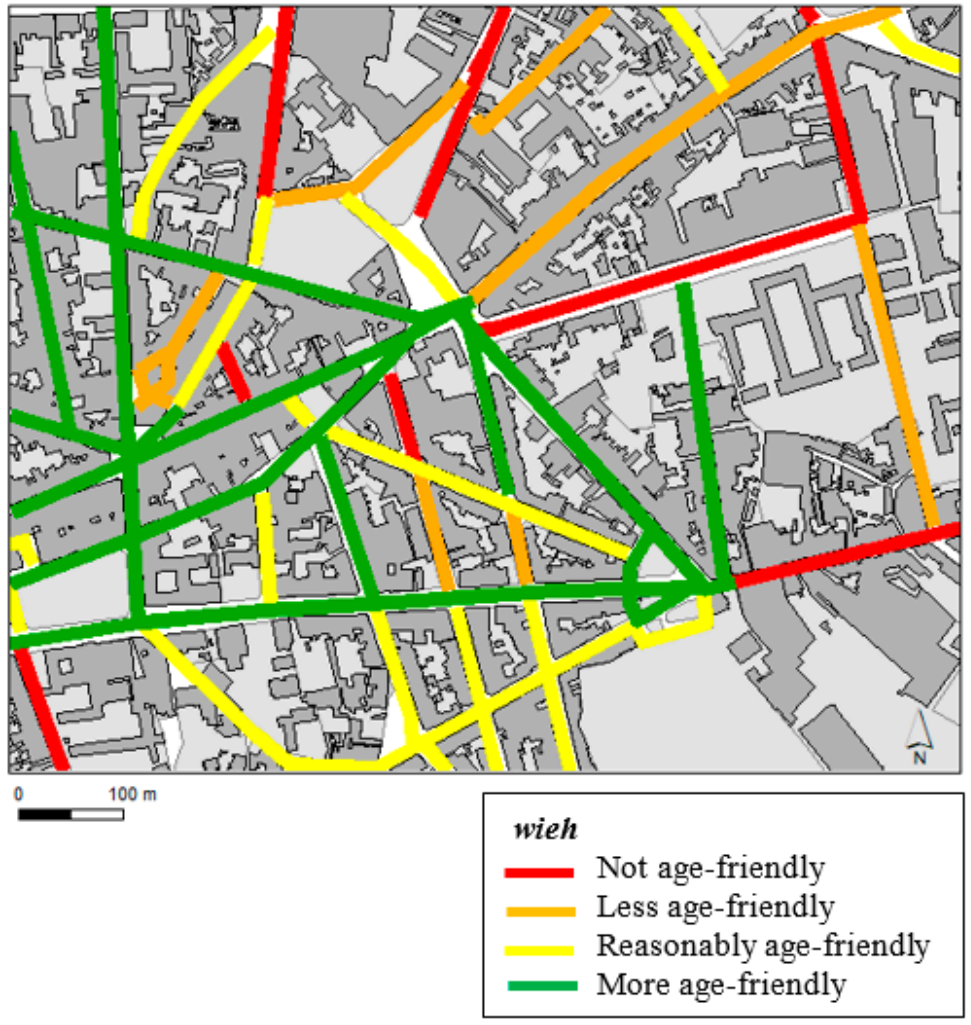

(b)

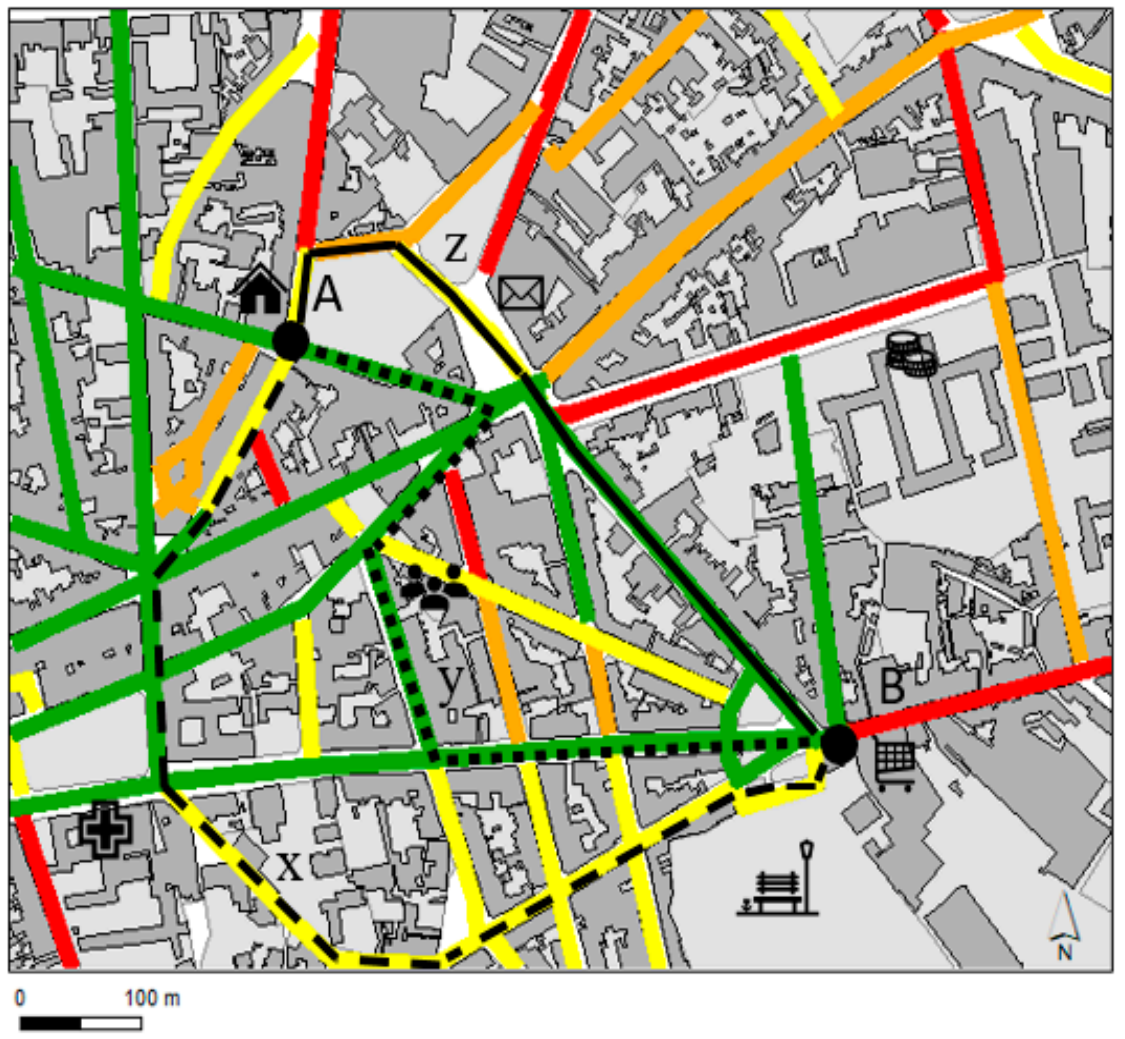

(c)

Figure 5. (a) Identifying destinations, (b) calculating the WIEH, (c) mapping alternative routes from origin A (home) to destination B (e.g., supermarket). 


\subsection{Second Step-Integrating Slopes and Stairs}

This second step comprised the classification of each section of the pedestrian network according to Table 9, which defines the criteria for slopes and stairs. This ranking index, "is", uses discrete values varying between 1 and 4 .

Table 9. Index results for "is".

\begin{tabular}{ccccc}
\hline Index Values (is) & Slopes (sl) & Stairs & Result \\
\hline 1 & Suitable slopes & $<5 \%$ & No stairs & most recommended \\
2 & Suitable slopes & $<5 \%$ & Stairs/small number of steps & recommended \\
3 & Acceptable slopes & $5-8 \%$ & Stairs/significant number of steps & less recommended \\
4 & Steep slopes & $>8 \%$ & Stairs/large number of steps & not recommended \\
\hline
\end{tabular}

Table 10 combines the quality of pedestrian network with the index results for "is".

Table 10. Classification of the WIEH.

\begin{tabular}{|c|c|c|c|}
\hline & WIEH & Routes Classification & Observations \\
\hline $\begin{array}{c}1-4 \\
\text { A }\end{array}$ & $\leq 0,5$ & Not age-friendly & $\begin{array}{l}\text { Routes not at all recommended-No quality } \\
\text { of pedestrian network and/or existence of } \\
\text { steep slopes and/or large number of steps }\end{array}$ \\
\hline $1-4 \mathrm{~B}$ & $>0.5$ and $\leq 1$ & Less age-friendly & $\begin{array}{l}\text { Routes that should be avoided-Unsuitable } \\
\text { quality of pedestrian network and/or } \\
\text { inexistence of acceptable slopes and/or } \\
\text { significant number of steps }\end{array}$ \\
\hline $1-4 \mathrm{C}$ & $>1$ and $\leq 2.5$ & Reasonably age-friendly & $\begin{array}{c}\text { Routes that can be considered-Acceptable } \\
\text { quality of pedestrian network, reasonably } \\
\text { suitable slopes and stairs }\end{array}$ \\
\hline $1-4 \mathrm{D}$ & $>2.5$ and $\leq 3$ & More age-friendly & $\begin{array}{c}\text { Routes that are highly } \\
\text { recommended-Good \& suitable quality of } \\
\text { pedestrian network, with reduced slopes } \\
\text { and no stairs }\end{array}$ \\
\hline
\end{tabular}

\subsection{Third Step—Calculating Age-Friendly Routes}

This third step, illustrated in Figure 5a-c, aimed to position the elderly in relation to their most frequented spaces during their daily routines (e.g., supermarkets, churches, groceries, pharmacies, day-care centers, etc.).

First, the identification of potential destinations was undertaken and marked on the map layers, from among facilities, commerce, and other interest points for the elderly, either residents or tourists (Figure 5a).

Secondly, the WIEH for each section of the pedestrian network was calculated (Figure 5b).

Lastly, the elderly user was positioned at origin point A (potentially, their home) and different routes at an adequate distance for a pedestrian to walk were calculated toward destination point $B$ (hypothetically, a supermarket) (Figure 5c); the walking distance considered adequate ranges from $400 \mathrm{~m}$ to $800 \mathrm{~m}[65,66]$.

For the next step, the selection of the best walking route is presented, combining walkability and health improvement.

\subsection{Fourth Step—Selecting the "Heart-Friendly Route"}

Based on a range of possible routes obtained through the previous step, and considering that paths with "is" value equal to 4 were removed from the final map, this fourth step focused on selecting the most recommended route for an elderly person, keeping in mind the intersection of space adequacy, walking distance, and walking time (Figure 6). 


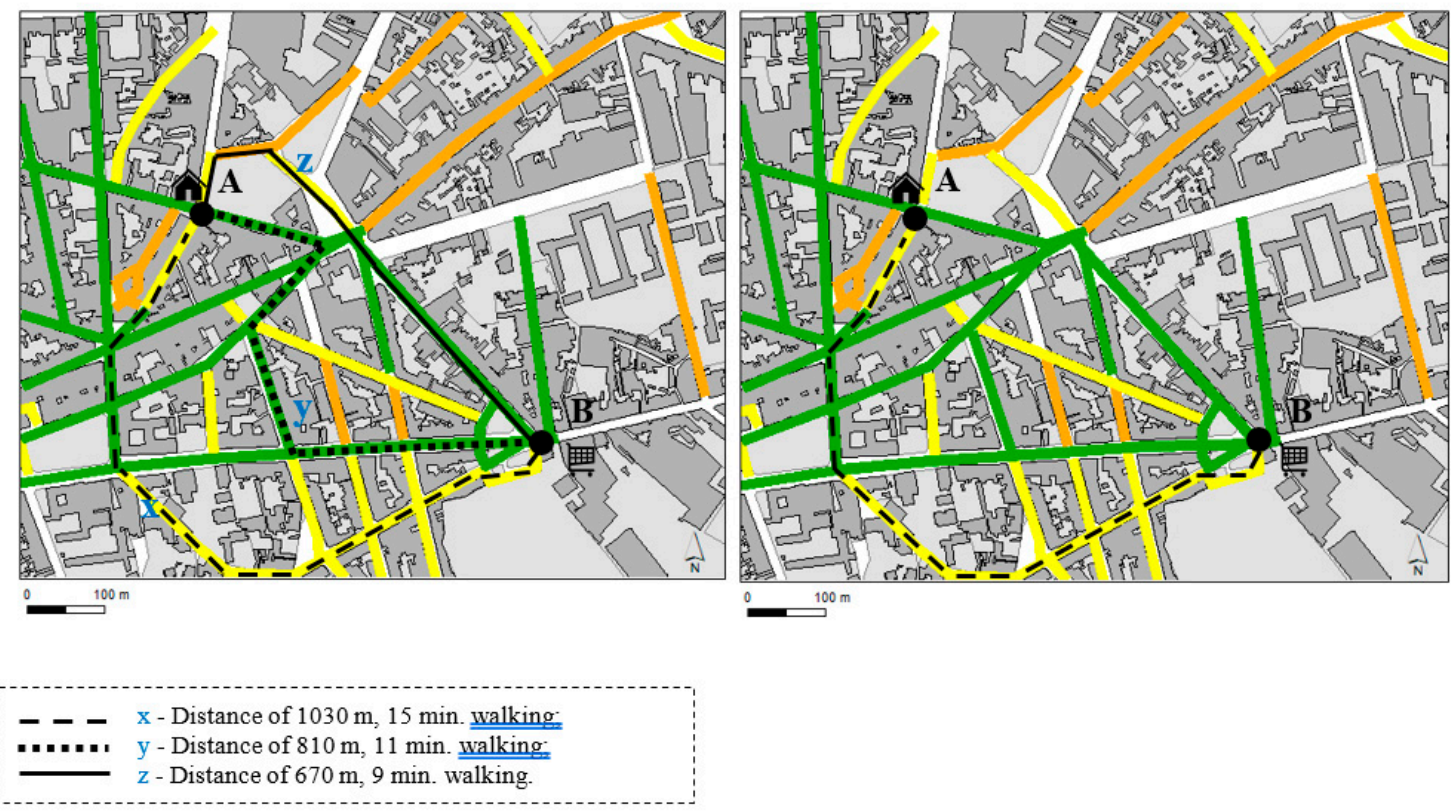

Figure 6. Selecting the "heart-friendly" route.

Considering an average step length of $68 \mathrm{~cm}$ (fast walking speed) to cover $1030 \mathrm{~m}$ (route $\mathrm{x}$ ), an elderly person (age group 60-69) will take approximately $15 \mathrm{~min}$ to walk that distance. In order to travel $810 \mathrm{~m}$ (route y), it will take them about $11 \mathrm{~min}$, and to travel $670 \mathrm{~m}$ (route $\mathrm{z}$ ), it will take them about $9 \mathrm{~min}$. Although route $\mathrm{z}$ represents the shortest distance, route $\mathrm{x}$ allows the user to walk the recommended time according to physical exercise baselines, extending into a walk of $30 \mathrm{~min}$ if we also take into account the return trip. This is, therefore, the "heart-friendly route".

Thus, when considering alternative paths from origin point $\mathrm{A}$ to destination point $\mathrm{B}$, the selection is based on the following criteria:

- The route with the greatest number of sections best classified according to the WIEH (green-colored routes), and

- The route that allows the elderly to walk at a "fast walking speed" during a desirable time period of $30 \mathrm{~min}$.

We emphasize that the main purpose was to select a route that allows the elderly to use public space as an "outdoor gymnasium". By following the "heart-friendly route", elderly people can exercise daily during their routine walk, receiving direct and quantifiable health benefits. As an example, in the given scenario (Figure 6), if an older-age adult chooses route $x$ from home to the supermarket, this person will walk the distance of $1030 \mathrm{~m}$ twice, including the return trip; thus, they will be spending more than $30 \mathrm{~min}$ at a moderate walking speed. This person's heart rate will reach 78-132 bpm, corresponding to 50 to $85 \%$ of the "heart rate maximum average" (Table 3), which is considered a good interval to achieve direct health benefits, according to the literature presented in Section 2.

\section{Concluding Remarks and Expected Outcomes of the WIEH}

Most of the research on the adequacy of public spaces to the elderly focuses on identifying obstacles and problems around the city. Also, when looking at available literature on elderly health, studies present a bias toward particular aspects of health. Thus, there is a research gap in what concerns the connection between these two fields of knowledge.

This paper intended to fill this gap by proposing a conceptual framework to develop a Walkability Index for Elderly Health (WIEH), based on initial assumptions collected from each of the aforementioned areas of research. The WIEH is designed according to four sequential steps, starting by (1) analyzing public spaces and characterizing their quality for walking, then (2) considering the slopes and existence 
of stairs, (3) calculating different routes for the elderly in their daily routines or when walking to points of interest, and, lastly, (4) selecting the "heart-friendly route" for elderly people. It combines criteria for the most adequate route regarding the quality of public spaces (including variables from urban tissue, urban scenery, and safety) with recommended routes regarding slopes and existence of stairs. Ultimately, these factors are also combined with health issues linked to aging, with the objective of promoting direct benefits for the elderly's health during their daily routines. The Index is, thus, designed for the elderly, although it can be used by anyone from any age group or physical condition, based on the assumption that a good city for the elderly is a good city for anyone.

The presentation of the WIEH evidences its usefulness as a support tool for the elderly in their decisions to walk around the city, bringing together aspects related to the physical characteristics of the pedestrian network, combined with health issues. The main objective of this Index is to contribute to active and healthy aging, but also to provide end users (elderly or non-elderly, residents or non-residents) with a tool capable of assisting them in selecting more age-friendly routes. It also aims to help decision makers, urban planners, and designers to create better age-friendly spaces and walking itineraries (through maps, street signs, urban furniture, etc.). Moreover, it can provide useful walkability-related information to public or private elderly-service providers (day-care centers, nursing homes, and communities group associations, among others), thus allowing them to guide elderly people toward better walking places in the city or neighborhood.

There may be some limitations in applying this framework to real cases, due to contextual conditions: On one hand, an overall lack of quality of public spaces (e.g., historic centers easily present low standards of quality due to narrow streets, inadequate pavements, existence of stairs, etc.); on the other hand, there might be a lack in the provision of services, commerce, or points of interest around the elderly person's home. These limitations may hamper the selection of routes, decreasing the level of adequacy for the elderly.

Finally, the conceptual framework of the WIEH is expected to serve as the basis for the development of an interactive mobile app or web-based platform, by combining a way-finder tool with GIS maps and layers. In order to make the most use of these digital tools, they can be developed to be compatible with Google Maps or similar platforms. Nevertheless, on-site maps (placed on physical information boards) are also relevant, as most elderly people are not digitally savvy. The use of the WIEH tool, with its detailed classification of each section of path/street into levels, will support the elderly in making more conscious and informed decisions regarding their daily walking routes, promoting a healthier way of living by taking advantage of the public space as an "outdoor gymnasium". In a future testing phase, other urban qualitative aspects and perceptual qualities, such as those obtained through questionnaires, can be integrated into the WIEH design and implemented using a case-study approach. Direct observation of real-life situations was not an objective of this study. However, its future implementation in the study area, together with the integration of (other) urban qualitative dimensions (scale and variety, transparency, coherence, visual complexity, lighting, green areas, colors, pattern, softness, and street vitality, etc.), could provide interesting perspectives regarding further studies and debates. As to another future path, a partnership with city councils and other public and social institutions (day-care centers, seniors' residences, etc.) would also help strengthen the implementation of the WIEH and contribute to the success of the mobility tool.

Author Contributions: Conceptualization, F.A; S.C.; Methodology, F.A., S.C.; Software, F.A., S.C., J.M.; Validation, F.A., S.C., A.R. and A.B.S.; Formal Analysis, F.A., S.C., A.R. and J.M.; Investigation, F.A., S.C., A.R., A.B.S., J.M. and I.C.; Resources, F.A., S.C., A.R. and A.B.S.; Data Curation, F.A., S.C., A.R., A.B.S., J.M. and I.C.; Writing-Original Draft Preparation, F.A., S.C., A.R., A.B.S., J.M. and I.C.; Writing-Review \& Editing, F.A., S.C. and A.R..; Visualization, F.A., S.C., A.R., A.B.S., J.M. and I.C.; Supervision, F.A. and S.C.; Project Administration, F.A., S.C., A.R.; Funding Acquisition, A.R. All authors have read and agreed to the published version of the manuscript.

Funding: This research was funded by national funds through the Fundação para a Ciência e Tecnologia/Ministério da Ciência, Tecnologia e Ensino Superior (FCT/MCTES) - Programa de Investimento e Despesas de Desenvolvimento da Administração Central (PIDDAC), under the MIT Portugal Programme, project reference MITEXPL/STS/0065/2017. 
Conflicts of Interest: The authors declare no conflict of interest.

\section{References}

1. Tacken, M. Mobility of the elderly in time and space in the Netherlands: An analysis of the Dutch National travel survey. Transportation 1998, 25, 379-393. [CrossRef]

2. Rosenbloom, S. Sustainability and automobility among the elderly: An international assessment. Transportation 2001, 28, 375-408. [CrossRef]

3. Burkhardt, J.E. Better transportation services for older persons. Transp. Res. Rec. J. Transp. Res. Board 2003, 1843, 105-112. [CrossRef]

4. Sundling, C. Travel behavior change in older travelers: Understanding critical reactions to incidents encountered in public transport. Int. J. Environ. Res. Public Health 2015, 12, 14741-14763. [CrossRef] [PubMed]

5. Flores, R.; Caballer, A.; Alarcón, A. Evaluation of an age-friendly city and its effect on life Satisfaction: A two-stage study. Int. J. Environ. Res. Public Health 2019, 16, 5073. [CrossRef] [PubMed]

6. WHO. Global Age-Friendly Cities: A Guide; World Health Organization: Geneva, Switzerland, 2007.

7. Zeitler, E.; Buys, L.; Aird, R.; Miller, E. Mobility and active ageing in suburban environments: Findings from in-depth interviews and person-based GPS tracking. Curr. Gerontol. Geriatr. Res. 2012. [CrossRef]

8. Aguiar, B.; Macário, R. The need for an elderly centred mobility policy. Transp. Res. Procedia 2017, 25, 4355-4369. [CrossRef]

9. Zaidi, A.; Gasior, K.; Zólyomi, E.; Schmidt, A.; Rodrigues, R.; Marin, B. Measuring active and healthy ageing in Europe. J. Eur. Soc. Policy 2017, 27, 138-157. [CrossRef]

10. Cinderby, S.; Cambridge, H.; Attuyer, K.; Bevan, M.; Croucher, K.; Gilroy, R.; Swallow, D. Co-designing urban living solutions to improve older people's mobility and well-being. J. Urban Health 2018, 95, 409-422. [CrossRef]

11. WHO. Active Ageing-A Policy Framework; World Health Organization: Geneva, Switzerland, 2002.

12. Rubenstein, L. Falls in older people: Epidemiology, risk factors and strategies for prevention. Age Ageing 2006, 35, 37-41. [CrossRef]

13. Santinha, G.; Costa, C.; Diogo, S. How are local policies promoting older people's mobility? A Case Study. Urban Sci. 2018, 2, 63. [CrossRef]

14. Fernández-Ballesteros, R. Positive ageing: Objective, subjective, and combined outcomes. Electron. J. Appl. Psychol. 2011, 7, 22-30. [CrossRef]

15. Reyer, M.; Fina, S.; Siedentop, S.; Schlicht, W. Walkability is only part of the story: Walking for transportation in stuttgart, germany. Int. J. Environ. Res. Public Health 2014, 11, 5849-5865. [CrossRef] [PubMed]

16. Li, X.; Ghosh, D. Associations between body mass index and urban "green" streetscape in cleveland, Ohio, USA. Int. J. Environ. Res. Public Health 2018, 15, 2186. [CrossRef] [PubMed]

17. Southworth, M. Designing the walkable city. J. Urban Plan. Dev. 2005, 131, 246-257. [CrossRef]

18. Appolloni, L.; Corazza, M.; D'Alessandro, D. The pleasure of walking: An innovative methodology to assess appropriate walkable performance in urban areas to support transport planning. Sustainability 2019, 11, 3467. [CrossRef]

19. Hosler, A.S.; Gallant, M.P.; Riley-Jacome, M.; Rajulu, D.T. Relationship between objectively measured walkability and exercise walking among adults with diabetes. J. Environ. Public Health 2014, 542123. [CrossRef]

20. Forsyth, A. What is a walkable place? The walkability debate in urban design. Urban Des. Int. 2015, 20, 274-292. [CrossRef]

21. Nuzir, F.; Dewancker, B. Redefining place for walking: A literature review and key-elements conception. Theor. Empir. Res. Urban Manag. 2016, 11, 59-76. Available online: http://um.ase.ro/no111/4.pdf (accessed on 21 August 2020).

22. Herrmann, T.; Boisjoly, G.; Ross, N.; El-Geneidy, A. The missing middle: Filling the gap between walkability and observed walking behavior. Transp. Res. Rec. J. Transp. Res. Board 2017, 2661, 103-110. [CrossRef] 
23. Julius, L.M.; Brach, J.S.; Wert, D.M.; Vanswearingen, J.M. Perceived Effort of Walking: Relationship With Gait, Physical Function and Activity, Fear of Falling, and Confidence in Walking in Older Adults With Mobility Limitations. 2012. Available online: https://academic.oup.com/ptj/article-abstract/92/10/1268/2735112 (accessed on 19 December 2019).

24. Silva, A.M.C.B.; da Cunha, J.R.R.; da Silva, J.P.C. Estimation of pedestrian walking speeds on footways. Proc. Inst. Civil Eng. Munic. Eng. 2014, 167, 32-43. [CrossRef]

25. Murrau, R.; Pinna, F. Pedestrian behaviour in urban area. In Proceedings of the International Conference on Traffic and Transport Engineering (ICTTE), Belgrade, Serbia, 27-28 November 2014; pp. 27-28.

26. Burton, E.; Mitchell, L. Inclusive Urban Design-Streets for Life; Elsevier: Oxford, UK, 2006.

27. Wheat, M.E.; York, N.; Lo, B.; Mcphee, S.J. Wheat ME: Exercise in the elderly. West J. Med. 1987, 147, 477-480. [PubMed]

28. American Heart Association. Know Your Target Heart Rates for Exercise, Losing Weight and Health. 2015. Available online: https://www.heart.org/en/healthy-living/fitness/fitness-basics/target-heart-rates (accessed on 3 December 2019).

29. Öberg, T.; Karsznia, A.; Öberg, K. Basic gait parameters: Reference data for normal subjects, 10-79 years of age. J. Rehabil. Res. Dev. 1993, 30, 210-223. [PubMed]

30. Hollman, J.H.; McDade, E.M.; Petersen, R.C. Normative spatiotemporal gait parameters in older adults. Gait Posture 2011, 34, 111-118. [CrossRef] [PubMed]

31. Tudor-Locke, C.; Craig, C.L.; Aoyagi, Y.; Bell, R.; Croteau, K.; De Bourdeaudhuij, I.; Ewald, B.; Gardner, A.W.; Hatano, Y.; Lutes, L.; et al. How many steps/day are enough? For older adults and special populations. Int. J. Behav. Nutr. Phys. Act. 2011, 8. [CrossRef] [PubMed]

32. Health in Aging Foundation. Walking Tips for Older Adults. 2019. Available online: https:/go4life.nia.nih. gov/ (accessed on 2 December 2019).

33. Su, M.; Du, Y.; Liu, Q.; Ren, Y.; Kawachi, I.; Lv, J.; Li, L. Objective assessment of urban built environment related to physical activity-Development, reliability and validity of the China Urban Built Environment Scan Tool (CUBEST). BMC Public Health 2014, 14. [CrossRef] [PubMed]

34. Talavera-Garcia, R.; Soria-Lara, J. Q-PLOS, developing an alternative walking index. A method based on urban design quality. Cities 2015, 45,7-17. [CrossRef]

35. Aranoa, M.; Allo, C.; Serrano, I. Walkability City Tool (WCT): Measuring walkability. In Proceedings of the 22nd International Sustainable Development Research Society Conference (ISDRS 2016), School of Science and Technology, Universidade Nova de Lisboa, Lisbon, Portugal, 13-15 July 2016; Volume 1, pp. 789-800.

36. Direção-Geral da Saúde. A Atividade Física e o Desporto: Um Meio Para Melhorar a Saúde e o Bem-Estar; MF/Divisão de Informação; Comunicação e Educação para a Saúde: Lisboa, Portugal, 2007.

37. King, A.; King, D. Physical activity for an aging population. Public Health Rev. 2010, 32, 401-426. [CrossRef]

38. Laatikainen, T.; Haybatollahi, M.; Kyttä, M. Environmental, individual and personal goal influences on older adults' walking in the helsinki metropolitan area. Int. J. Environ. Res. Public Health 2019, 16, 58. [CrossRef]

39. Sundquist, K.; Eriksson, U.; Kawakami, N.; Skog, L.; Ohlsson, H.; Arvidsson, D. Neighborhood walkability, physical activity, and walking behavior: The Swedish Neighborhood and Physical Activity (SNAP) study. Soc. Sci. Med. 2011, 72, 1266-1273. [CrossRef]

40. Reiner, M.; Niermann, C.; Jekauc, D.; Woll, A. Long-term health benefits of physical activity-A systematic review of longitudinal studies. BMC Public Health 2013, 13, 813. [CrossRef]

41. Daskalopoulou, C.; Stubbs, B.; Kralj, C.; Koukounari, A.; Prince, M.; Prina, A.M. Physical activity and healthy ageing: A systematic review and meta-analysis of longitudinal cohort studies. Ageing Res. Rev. 2017, 38, 6-17. [CrossRef] [PubMed]

42. Richardson, A.; Troxel, W.; Ghosh-Dastidar, M.; Beckman, R.; Hunter, G.; DeSantis, A.; Colabianchi, N.; Dubowitz, T. One size doesn't fit all: Cross-sectional associations between neighborhood walkability, crime and physical activity depends on age and sex of residents. BMC Public Health 2017, 17. [CrossRef] [PubMed]

43. U.S. Department of Health and Human Services. Physical Activity Guidelines for Americans, 2nd ed.; Department of Health and Human Services: Washington, DC, USA, 2018. Available online: https://health. gov/sites/default/files/2019-09/Physical_Activity_Guidelines_2nd_edition.pdf (accessed on 3 March 2020).

44. Perchoux, C.; Brondeel, R.; Wasfi, R.; Klein, O.; Caruso, G.; Vallée, J.; Klein, S.; Thierry, B.; Dijst, M.; Chaix, B.; et al. Walking, trip purpose, and exposure to multiple environments: A case study of older adults in Luxembourg. J. Transp. Health 2019, 13, 170-184. [CrossRef] 
45. Government Department of Health Ageing of Australia. Choose Health: Be Active. 2005. Available online: www.ag.gov.au/cca (accessed on 2 December 2019).

46. Nelson, M.; Rejeski, W.; Blair, S.; Duncan, P.; Judge, J.; King, A.; Macera, C.; Castaneda-Sceppa, C. Physical activity and public health in older adults. Circulation 2007, 116, 1094-1105. [CrossRef]

47. Murphy, M.; Donnelly, P.; Breslin, G.; Shibli, S.; Nevill, A. Does doing housework keep you healthy? The contribution of domestic physical activity to meeting current recommendations for health. BMC Public Health 2013, 13, 966. [CrossRef]

48. National Health Service. Physical Activity Guidelines for Older Adults. 2018. Available online: https: //www.nhs.uk/live-well/exercise/physical-activity-guidelines-older-adults/ (accessed on 7 January 2020).

49. American Academy of Family Physicians. Exercise and Seniors. 2019. Available online: https://familydoctor. org/exercise-seniors/ (accessed on 11 April 2020).

50. Direção-Geral da Saúde. (n.d.) Programa Nacional Para a Promoção da Atividade Física. Available online: https://www.dgs.pt/programa-nacional-para-a-promocao-da-atvidade-fisica/perguntas-e-respostas. aspx (accessed on 20 January 2020).

51. Australian Government-Department of Health. (n.d.); Tips and Ideas for Older Australians (65 years and older). Available online: https://www1.health.gov.au/internet/main/publishing.nsf/ Content/F01F92328EDADA5BCA257BF0000E720D/\$File/Tips\&Ideas-Older-Aust-65plus.pdf (accessed on 3 December 2019).

52. Schimpl, M.; Moore, C.; Lederer, C.; Neuhaus, A.; Sambrook, J.; Danesh, J.; Ouwehand, W.; Daumer, M. Association between walking speed and age in healthy, free-living individuals using mobile accelerometry-A cross-sectional study. PLoS ONE 2011, 6. [CrossRef]

53. Meeder, M.; Aebi, T.; Weidmann, U. The influence of slope on walking activity and the pedestrian modal share. Transp. Res. Procedia 2017, 27, 141-147. [CrossRef]

54. Ferraro, R.; Pinto-Zipp, G.; Simpkins, S.; Clark, M. Effects of an inclined walking surface and balance abilities on spatiotemporal gait parameters of older adults. J. Geriatr. Phys. Ther. 2013, 36, 31-38. [CrossRef]

55. Hunter, L.; Hendrix, E.; Dean, J. The cost of walking downhill: Is the preferred gait energetically optimal? J. Biomech. 2010, 43, 1910-1915. [CrossRef]

56. Wall-Scheffler, C.M. Sex differences in incline-walking among humans. Integr. Comp. Biol. 2015, 55, 1155-1165. [CrossRef] [PubMed]

57. Kawata, A.; Shiozawa, N.; Makikawa, M. Estimation of energy expenditure during walking including up/down hill. In World Congress on Medical Physics and Biomedical Engineering 2006, Proceedings of the IFMBE, Seoul, Korea, 27 August -1 September 2006; Magjarevic, R., Nagel, J.H., Eds.; Springer: Berlin/Heidelberg, Germany, 2007; Volume 14.

58. Sun, J.; Walters, M.; Svensson, N.; Lloyd, D. The influence of surface slope on human gait characteristics: A study of urban pedestrians walking on an inclined surface. Ergonomics 1996, 39, 677-692. [CrossRef] [PubMed]

59. Kawamura, K.; Tokuhiro, A.; Takechi, H. Gait analysis of slope walking: A study on step length, stride width, time factors and deviation in the center of pressure. Acta Med. Okayama 1991, 45, 179-184. [CrossRef] [PubMed]

60. Seco, A.; Macedo, J.; Costa, A. Manual do Planeamento de Acessibilidades e Transportes 08. Comissão de Coordenação e Desenvolvimento Regional do Norte. 2008, p. 52. Available online: http://www.estgv.ipv.pt/PaginasPessoais/vasconcelos/Documentos/ManualdeAcessibilidades/ ManuaisCCDRNmiolo_AF/08Peoes_AF.pdf (accessed on 3 December 2019).

61. Navalta, J.; Sedlock, D.; Park, K. Physiological responses to downhill walking in older and younger individuals. J. Exerc. Physiol. 2004, 7, 45-51.

62. Mazuroski, A. Mobilidade Pedonal Urbana-Contribuições Para o Planeamento e Auditoria do Espaço Público na Mobilidade de Idosos. Master's Thesis, School of Science and Technology, Universidade Nova de Lisboa, Lisbon, Portugal, 2018.

63. Diário da República 2006-Decreto-Lei n. ${ }^{\circ}$ 163/2006 de 8 de agosto. Ministério do Trabalho e da Solidariedade Social. Diário da República n. ${ }^{\circ}$ 152/2006, Série I de 2006-08-08. Available online: https://data.dre.pt/eli/declei/163/2006/08/08/p/dre/pt/html (accessed on 10 December 2019). 
64. IMTT—Instituto da Mobilidade e dos Transportes Terrestres, I.P. Rede Pedonal—Princípios de planeamento e desenho. Lisboa: IMTT (Title transl: IMTT—Portuguese Institute for Mobility and Land Transports (IMTT). 2011. Available online: http://server109.webhostingbuzz.com/ \{\}transpor/conferenciamobilidade/pacmob/ rede_pedonal/Rede_Pedonal_Principios_de_Planeamento_\%20e_Desenho_Marco2011.pdf (accessed on 13 January 2020).

65. Carstens, D.Y. Site Planning and Design for the Elderly: Issues, Guidelines, and Alternatives; John Wiley \& Sons: Hoboken, NI, USA, 1993.

66. Goodman, R.; Tolley, R. The Decline of Everyday Walking in the UK: Explanations and Policy Implications; Woodhead Publishing: Sawston/Cambridge, UK, 2003.

67. Federal Ministry for Economic Cooperation and Development. Urban Mobility. Strategies for Liveable Cities; FMECD: Bonn, Germany, 2016.

68. Schmid, J. La Relation Entre L'environnement Construit et L'activité Physique Sous Forme de Déplacements à Pied; Mémoire de licence; Faculté des géosciences et de l'environnement; Université de Lausanne: Lausanne, Switzerland, 2006.

69. Chudyk, A.; Winters, M.; Moniruzzaman, M.D.; Maureenm, A.; Gouls, J.; McKay, H. Destinations matter: The association between where older adults live and their travel behaviour. J. Transp. Health 2015, 2, 50-57. [CrossRef]

70. Abrantes, N. A Requalificação dos Espaços Públicos nos Conjuntos de Habitação Económica no Porto- O Desenho como Instrumento Social. Ph.D. Thesis, Faculty of Engineering, University of Porto, Porto, Portugal, 2016.

71. Pfeiffer, D.; Cloutier, S. Planning for happy neighborhoods. J. Am. Plan. Assoc. 2016, 82, 267-279. [CrossRef]

72. Michael, Y.; Beard, T.; Choi, D.; Farquhar, S.; Carlson, N. Measuring the influence of built neighborhood environments on walking in older adults. J. Aging Phys. Act. 2006, 14, 302-312. [CrossRef]

73. ARUP, HelpAge International, Intel, \& Systematica. Shaping Ageing Cities: 10 European Case Studies; Arup, Help Age International, Intel, Systematica: London, UK, 2015.

74. Talen, E.; Koschinsky, J. The Walkable Neighborhood: A Literature Review. Int. J. Sustain. Land Use Urban Plan. 2013, 1, 42-63. Available online: https://www.pdffiller.com/jsfiller-desk18/ ?requestHash=48be864df6d7f2ccb7cc8f6935d32787d6b74a7c7d15b9ffcc08e627c23bfc2b\&projectId=520700120\# 8ba8be959b85eef34960225e06d90305 (accessed on 21 August 2020). [CrossRef]

75. Sing, R. Factors affecting walkability of neighborhoods. Urban planning and architecture design for sustainable development, upadsd 14-16 October. Procedia Soc. Behav. Sci. 2016, 216, 643-654. Available online: https://www.sciencedirect.com/science/article/pii/S187704281506228X (accessed on 11 February 2020).

76. Jacobs, J. The Death and Life of Great American Cities; Random House: New York, NY, USA, $1961 ;$ p. 474. Available online: http://www.petkovstudio.com/bg/wp-content/uploads/2017/03/The-Death-and-Life-ofGreat-American-Cities_Jane-Jacobs-Complete-book.pdf (accessed on 23 April 2020).

77. Goffman, E. Behavior in Public Places; Notes on the Social Organization of Gathering; Free Press of Glencoe: New York, NY, USA, 1963; p. 256. Available online: https://osf.io/zth8x/ (accessed on 21 August 2020).

78. Goffman, E. Interaction Ritual: Essays in Face-to-Face Behavior; Routledge: New York, NY, USA, 2017 ; p. 280. First Published 1967; Available online: https://doi.org/10.4324/9780203788387 (accessed on 20 August 2020).

79. Lemert and Branaman. The Goffman Reader; Blackwell: Cambridge, MA, USA, 1997; Available online: https://cdclv.unlv.edu/archives/interactionism/goffman/lemert97.pdf (accessed on 15 April 2020).

80. Newman, O. Defensible Space: Crime Prevention through Urban Design; Collier Books: New York, NY, USA, 1973.

81. Gehl, J. Life between Buildings: Using Public Space; Van Nostrand Reinhold: New York, NY, USA, 1987; p. 216.

82. Gehl, J. Cities for People; Island Press: New York, NY, USA, 2013; p. 288.

83. Whyte. City:Rediscovering the Center; Doubleday: New York, NY, USA, 1988.

84. Frank, L.; Sallis, J.; Saelens, B.; Leary, L.; Cain, K.; Conway, T.; Hess, P. The development of a walkability index: Application to the neighborhood quality of life study. Br. J. Sports Med. 2010, 44, 924-933. [CrossRef]

85. Walk Score. (n.d.) Walk Score Data Services-Walkability, Real Estate, and Public Health Data. Available online: https:/www.walkscore.com/professional/research.php (accessed on 2 December 2019). 
86. Rosa, M.; Martins, C.; Rodrigues, J. The development of indicators of sustainable mobility associated with an urbanism of proximity. In The Case of the City of Faro, INCREaSE, Proceedings of the 1st International Congress on Engineering and Sustainability in the XXI Century-INCREaSE 2017, 2018, Faro, Portugal, 11-13 October 2017; Mortal, A., Aníbal, J., Monteiro, J., Sequeira, C., Semião, J., da Silva, M., Oliveira, M., Eds.; Springer International Publishing: Berlin/Heidelberg, Germany, 2018; pp. 47-66.

87. Ekkel, E.; de Vries, S. Nearby green space and human health: Evaluating accessibility metrics. Landsc. Urban Plan. 2017, 157, 214-220. [CrossRef]

88. Higgs, C.; Badland, H.; Simons, K.; Knibbs, L.; Giles_Corti, B. The urban liveability index: Developing a policy-relevant urban liveability composite measure and evaluating associations with transport mode choice. Int. J. Health Geogr. 2019, 18. [CrossRef] [PubMed]

89. Ewing, R.; Handy, S. Measuring the unmeasurable: Urban design qualities related to walkability. J. Urban Des. 2009, 14, 65-84. [CrossRef]

90. Rebecchi, A.; Buffoli, M.; Dettori, M.; Appolloni, L.; Azara, A.; Castiglia, P.; D’Alessandro, D.; Capolongo, S. Walkable environments and healthy urban moves: Urban context features assessment framework experienced in milan. Sustainability 2019, 11, 2778. [CrossRef]

91. Hooper, P.; Boruff, B.; Beesley, B.; Badland, H.; Giles-Corti, B. Testing spatial measures of public open space planning standards with walking and physical activity health outcomes: Findings from the Australian national liveability study. Landsc. Urban Plan. 2018, 171, 57-67. [CrossRef]

92. Koohsari, M.; Badland, H.; Mavoa, S.; Villanueva, K.; Francis, J.; Hooper, P.; Owen, N.; Giles-Corti, B. Are public open space attributes associated with walking and depression? Cities 2018, 74, 119-125. [CrossRef]

93. Lu, Y. Using Google street view to investigate the association between street greenery and physical activity. Landsc. Urban Plan. 2019, 191. [CrossRef]

94. Romagosa, F. Physical health in green spaces: Visitors' perceptions and activities in protected areas around Barcelona. J. Outdoor Recreat. Tour. 2018, 23, 26-32. [CrossRef]

95. Bilal, U.; Díez, J.; Alfayate, S.; Gullón, P.; Del Cura, I.; Escobar, F.; Sandín, M.; Franco, M.; HHH Research Group. Population cardiovascular health and urban environments: The heart healthy hoods exploratory study in Madrid, Spain. BMC Med Res. Methodol. 2016, 16, 104. [CrossRef]

(C) 2020 by the authors. Licensee MDPI, Basel, Switzerland. This article is an open access article distributed under the terms and conditions of the Creative Commons Attribution (CC BY) license (http://creativecommons.org/licenses/by/4.0/). 